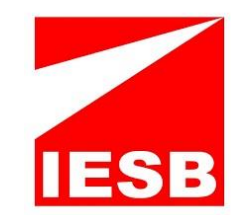

CENTRO UNIVERSITÁRIO

INSTITUTO DE EDUCAÇÃO SUPERIOR DE BRASÍLIA - IESB

RELAÇÕES INTERNACIONAIS

GENILDO PEREIRA GALVÃO

RÚSSIA, EM BUSCA DE SEU ESPAÇO NO NOVO CONTEXTO INTERNACIONAL

BRASÍLIA - DF

2018 
RÚSSIA, EM BUSCA DE SEU ESPAÇO NO NOVO CONTEXTO INTERNACIONAL

Trabalho de Conclusão de Curso apresentado ao curso de Relações Internacionais do Instituto de Educação Superior de Brasília, como requisito parcial para obtenção do grau de Bacharel em Relações Internacionais.

Orientador: Prof. MSc. Jose Alejandro Sebastian Barrios Diaz.

Brasília - DF 2018 


\section{RÚSSIA, EM BUSCA DE SEU ESPAÇO NO NOVO CONTEXTO INTERNACIONAL}

Trabalho de Conclusão de Curso apresentado ao curso de Relações Internacionais do Instituto de Educação Superior de Brasília, como requisito parcial para obtenção do grau de Bacharel em Relações Internacionais.

Orientador: Prof. MSc. Jose Alejandro Sebastian Barrios Diaz.

Brasília, de de 2018.

Banca Examinadora:

Prof ${ }^{\circ}$. Msc. Jose Alejandro Sebastian Barrios Diaz - Orientador Mestre no IESB

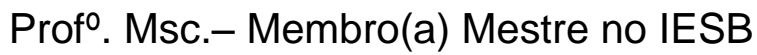




\section{DEDICATÓRIA}

Dedico este trabalho à minha mãe, Maria das Graças Lopes Pereira, uma mulher guerreira, fonte de toda minha inspiração e força, que sempre me impulsionou nos momentos mais difíceis. Obrigado Mãe!! 


\section{AGRADECIMENTOS}

Aos meus pais, Luís Gilmar Galvão e Maria das Graças Lopes Pereira, pelo incentivo e apoio incondicional.

Aos meus irmãos, Genilson Pereira Galvão, que contribuiu muito com este trabalho, e Venildo Pereira Galvão, e familiares que sempre estiveram ao meu lado, dando todo tipo de apoio e suporte necessário para que eu pudesse chegar a conclusão desta etapa da minha vida. De modo especial ao meu tio Antônio Gilberto Galvão, quase um segundo pai.

A esta universidade, seu corpo docente, direção e administração que oportunizaram um bom ambiente de estudos e oportunidades de melhorar meus conhecimentos. Em especial, aos professores: Marco Antônio de Meneses, Sérgio Florêncio, Paulo Sergio Mafra, Ricardo Pereira Mendes e de forma mais enfática, a Francisca Gallardo, uma professora incrivel e sem igual. A todos os professores que me ensinaram a importância do conhecimento no decorrer da minha vida.

Ao meu orientador Alejandro Sebastian Barrios Diaz, pelo suporte no tempo que the coube, pela sua paciência, suas correções e incentivos.

Aos meus amigos, que sempre estiveram me apoiando nos momentos de desmotivação. Em especial: Beatriz Baylo, Gabriella Martins, Nicholas Borges, João Luiz Soares Clementino, José Igor e María Teresa Chavarría Garcia.

A Haradja Paola e Elaine Luz, que me ajudaram grandemente na conclusão deste.

A todos que direta ou indiretamente fizeram parte da minha formação, o meu muito obrigado. 


\section{EPÍGRAFE}

"Não posso prever para os senhores a ação da Rússia. É uma charada envolta em mistério, dentro de um enigma. Mas talvez haja uma chave. Essa chave é o interesse nacional russo." (Winston Churchill, 1 de outubro de 1939) 


\section{RESUMO}

Após o fim da URSS e o seu desmembramento em quinze repúblicas a Federação Russa surge em meio a grandes problemas econômicos. Seu PIB e sua produção caiu cerca de $50 \%$, o desemprego chegou a atingir $25 \%$, o que gerou uma grande desmoralização russa internacionalmente. Mesmo herdeira do assento permanente no conselho de segurança da ONU e um grande arsenal nuclear, a Rússia perdeu seu status de grande potência. A partir desse contexto, o século XXI surge com grandes desafios à Rússia. Moscou agora precisa não somente se ajustar no novo contexto internacional, mas também, remontar sua própria identidade. Quando Putin chegou ao poder deu uma nova dinâmica à Rússia, promoveu melhorias internas e externas e trouxe o País de volta ao tabuleiro das Relações Internacionais. Além da promoção econômica, impulsionou também o orgulho nacional, trazendo símbolos dos tempos de glórias como a bandeira vermelha para as forças armadas (sem a foice e o martelo), hino e datas comemorativas da antiga URSS. Hoje verifica-se um crescente protagonismo russo no cenário internacional, buscando estar presente em todas as esferas econômicas, técnico-cientifica, cultural, política e militar. Na política externa Moscou busca uma ampliação de sua área de influência, em especial, na Eurásia. Por outro lado, o Ocidente percebendo a debilidade russa na década de 1990, começou a avançar na antiga zona de influência soviética através da União Europeia e principalmente da OTAN. Quando termina a Guerra Fria, a Otan tinha somente dezessete membros, duas décadas depois passa a ter vinte e oito membros, desses vinte e oito, doze da antiga zona de influência soviética. A partir de $2004 \mathrm{com}$ a nova rodada de expansão da OTAN e da UE, após as revoluções coloridas, em que dois países, de grande importância para Moscou, demostraram interesses em fazer parte das alianças ocidentais, a Rússia reage a estes eventos, invadindo a Ossétia do Sul e Abecásia na Guerra da Geórgia em 2008 e com a anexação da Crimeia em 2014, o que será abordado neste trabalho.

Palavras-chaves: Rússia, geopolítica, Guerra da Geórgia, Ucrânia. 


\section{RESUMEN}

Después del fin de la Unión de Repúblicas Socialistas Soviéticas (URSS) y su disgregación en quince repúblicas, la Federación Rusa surge en medio de grandes problemas económicos. Su PIB y su producción cayó cerca del 50\%, el desempleo alcanzó el $25 \%$, lo que generó una gran desmoralización rusa internacionalmente. Mismo que sea el heredero del asiento permanente en el consejo de seguridad de la Organización de Naciones Unidas (ONU) y de un gran arsenal nuclear, Rusia perdió su estatus de gran potencia. A partir de ese contexto, el siglo XXI surge con grandes desafíos para Rusia. Moscú ahora no sólo tiene que adaptarse al nuevo contexto internacional, sino también a remontar su propia identidad. Cuando Vladimir Putin llegó al poder dio una nueva dinámica a Rusia, promovió mejoras internas y externas y trajo al país de vuelta al tablero de las Relaciones Internacionales, además de la promoción económica, impulsó también el orgullo nacional, trayendo símbolos de los tiempos de gloria como la bandera roja para las fuerzas armadas (sin la hoz y el martillo), himno y fechas conmemorativas de la antigua URSS. Hoy se verifica un creciente protagonismo ruso en el escenario internacional, buscando estar presente en todas las esferas económicas, técnico-científicas, culturales, políticas y militares. En la política exterior Moscú busca una ampliación de su área de influencia, en especial, en Eurasia. Por otro lado, Occidente percibiendo la debilidad rusa en la década de 1990, empezó a avanzar en la antigua zona de influencia soviética a través de la Unión Europea (UE) y principalmente de la Organización del Tratado del Atlántico Norte (OTAN). Cuando termina la Guerra Fría, la OTAN tenía sólo diecisiete miembros, dos décadas después pasa a tener veintiocho miembros, de esos veintiocho, doce de la antigua zona de influencia soviética. A partir de 2004 con la nueva ronda de expansión de la OTAN y la UE, tras las revoluciones de colores, en las que dos países, de gran importancia para Moscú, demostraron intereses en formar parte de las alianzas occidentales, Rusia reacciona ante estos acontecimientos, invadiendo Osetia del Sur y Abjasia en la Guerra de Georgia en 2008 y con la anexión de Crimea en 2014, lo que será abordado en este trabajo.

Palabras-claves: Rusia, geopolítica, Guerra de Osetia del Sur, Ucrania. 


\section{LISTA DE ILUSTRAÇÕES}

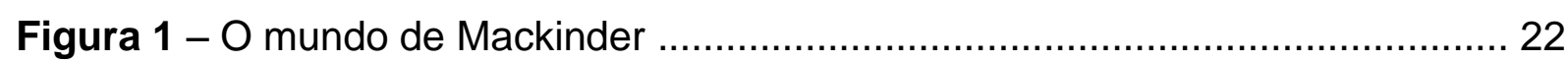

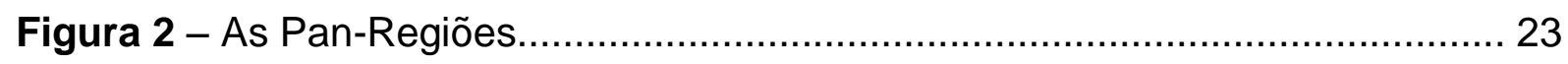

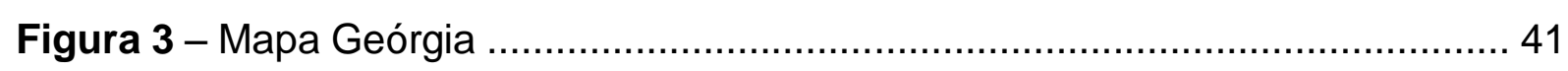

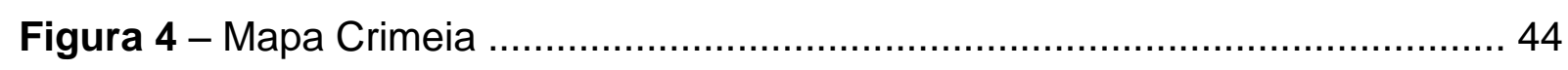

Figura 5 - Divisão política na Ucrânia ............................................................. 45

Figura 6 - Divisão de falantes ucranianos e russis na Ucrânia ................................ 46

\section{LISTA DE TABELAS}

Tabela 1 - Taxas de Crescimento Econômico Anual da URSS................................ 28

Tabela 2 - Crescimento Anual do PIB da Rússia ................................................... 34

\section{SUMÁRIO}

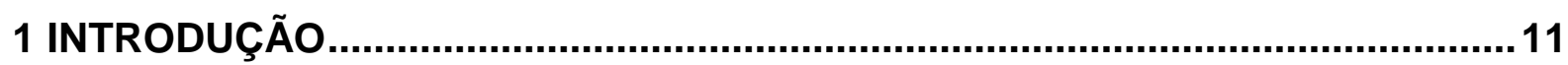

2 MARCO TEÓRICO .................................................................................14

2.1 RÚSSIA, OCIDENTAL, ORIENTAL OU ÚNICA? .........................................14

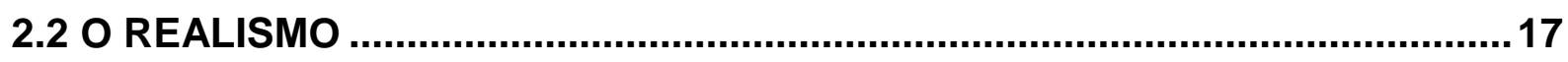

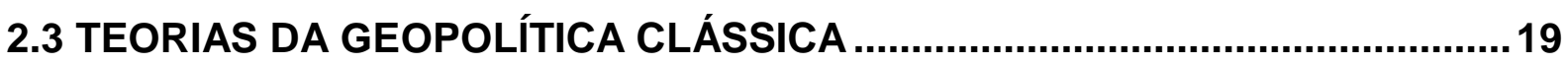

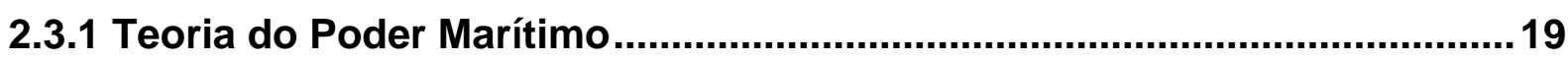

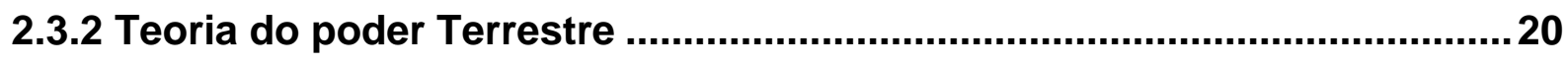

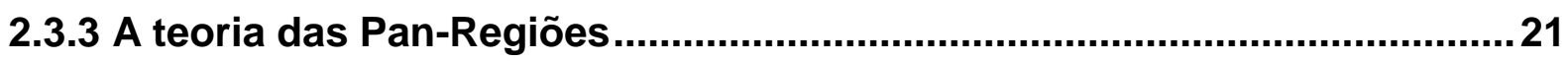

2.4 O EURASIANISMO: OS OCIDENTALISTAS, OS EXPANSIONISTAS E 0 .....22 NEOEURASIANISMO NA ATUAL CONJECTURA RUSSA ..................................22

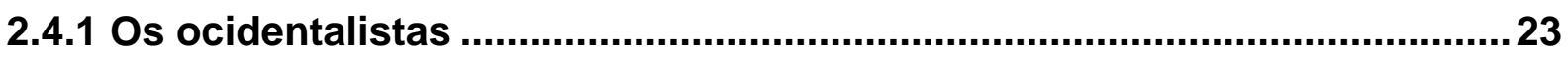

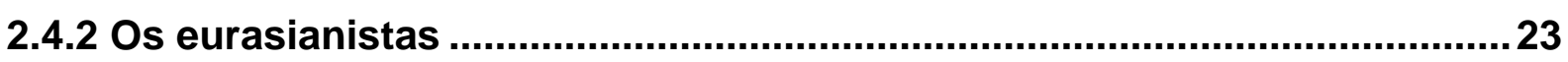

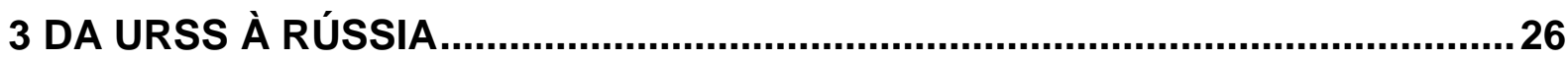

3.1 DA CAÓTICA RÚSSIA DE YELTSIN À RÚSSIA DE PUTIN ...........................32

3.2 DA RÚSSIA DE PUTIN, A RECONSTRUÇÃO DO ESTADO RUSSO ...............33

4 DA MOVIMENTAÇÃO RUSSA NO SUL DO CAÚCASO E UCRÂNIA ...................38

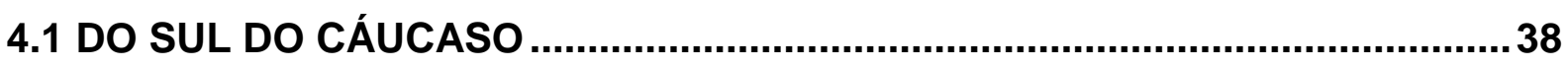

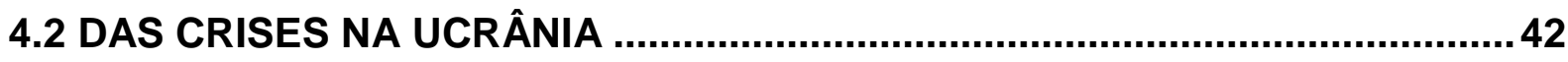


4.3 DA MOVIMENTAÇÂO EM OUTRAS REGIÕES …............................................. 46

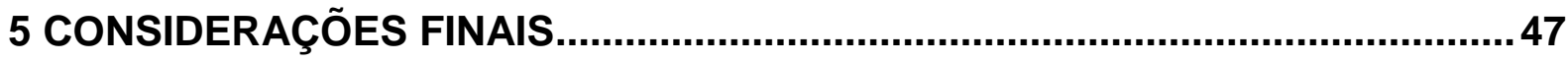

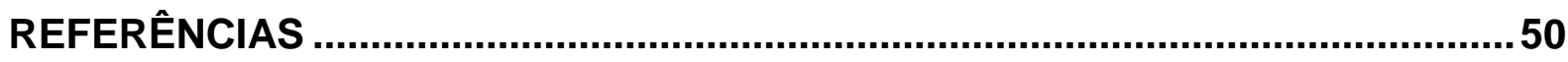

FILMOGRAFIA 


\section{INTRODUÇÃO}

A Rússia teve importância histórica no contexto do século $X X$, participou nas duas Grandes Guerras Mundiais, na segunda foi fundamental para a derrota da Alemanha. Em seu território realizou-se a primeira experiência da implantação de um sistema socialista real e depois como URSS foi, junto dos Estados Unidos, uma superpotência, contexto inédito na história.

Após a queda da União das Repúblicas Socialistas Soviéticas, a URSS e sua desfragmentação em quinze repúblicas, a Federação Russa surge com uma crise intensa no comando de Boris Yeltsin. A Rússia, na década de 1990 passa por grandes dificuldades econômicas, gerando uma crescente desmoralização no cenário internacional.

Com as reformas neoliberais implementadas por Yeltsin os problemas se agravaram, e a aceitação Ocidental, que o país tanto buscava, foi revertida em uma tentativa de contê-lo.

Quando Putin chegou ao poder em 1999 deu uma nova dinâmica à Rússia, promoveu melhorias internas e externas e trouxe a Rússia de volta ao tabuleiro das Relações Internacionais. A Rússia procura ter seu espaço de influência respeitado pelo Ocidente, e o Ocidente tenta contê-la pelo receio de sua ameaça.

Com esse ressurgimento, Moscou volta ao cenário internacional com sua política externa hoje mais confrontante com o Ocidente, que através da Organização do Tratado do Atlântico Norte, a OTAN e junto com a União Europeia, UE, busca introduzir os antigos satélites soviéticos em sua zona de influência e a Rússia tenta consolidar sua influência por meio de organizações como a Comunidade dos Estados Independentes, a CEI, União Econômica Eurasiana, UEE, e na parte asiática com a Organização para Cooperação de Xangai, OCX.

Quando terminou a Guerra Fria, houve o acordo de unificação alemã e da dissolução do Pacto de Varsóvia sem oposição russa, mas com duas condições: a Alemanha Oriental não iria se militarizar e a OTAN não traria os países do Pacto de Varsóvia à sua zona de influência. O que não aconteceu. A OTAN tinha somente dezessete membros, duas décadas depois passa a ter vinte e oito membros, desses vinte e oito, doze da antiga zona de influência soviética. 
Partindo desse contexto, surge como problemática as intervenções russas em países soberanos, como no caso da Geórgia e Ucrânia. Nesse sentido, quais as razões históricas e os motivos atuais que fizeram com que a Rússia ferisse a soberania de países vizinhos? Este trabalho parte da hipótese de que a Rússia vem buscando ter de volta o controle de sua antiga zona de influência, que com o aumento da influência da OTAN e UE, na Europa Oriental, utilizou a força como instrumento para racionalizar sua política na região. Dessa forma, a Rússia apenas estaria reagindo as expansões ocidentais.

A partir de 2004 com a nova rodada de expansão da OTAN e da UE, após as revoluções coloridas, em que dois países, de fundamental importância para Moscou, demostraram interesses em fazer parte das alianças Ocidentais, a Rússia reage a estes eventos, invadindo a Ossétia do Sul e Abecásia na Guerra da Geórgia em 2008 e com a anexação da Crimeia em 2014. A tentativa de incorporação da Ucrânia à zona Ocidental não poderia ser aceita pela Rússia. A Ucrânia é um dos países mais importante para a segurança russa, talvez o principal quando se trata da região europeia.

O objetivo geral da pesquisa é analisar a política externa russa neste início de século XXI, e buscar entender o porquê do uso da força em países como a Geórgia e Ucrânia e entender os interesses russos no chamado exterior próximo. Em termos objetivos e específicos, pretende-se:
a. Identificar a importância da presença russa na Ossétia do Sul e Abecásia na Geórgia;
b. Identificar os motivos da anexação da Crimeia ao território russo;
c. Apontar a importância da geopolítica na política externa russa.

Neste trabalho se usará a metodologia de pesquisa exploratória, com levantamentos bibliográficos, para se ter, dessa forma, maior proximidade com o objeto de estudo e uma visão mais ampla aproximada da realidade pesquisada. No segundo capítulo se abordará as duas principais correntes teóricas que estabelecem a condução da política externa russa. No terceiro capítulo se abordará um pouco do contexto histórico da URSS, os motivos de sua desfragmentação em 15 estados e o surgimento da Federação Russa, com o desígnio de entender melhor as aspirações e as debilidades do País no momento atual. No quarto capítulo será abordado a questão da movimentação russa na Geórgia e Ucrânia, explicando assim, os pretextos e 
desejos russos no seu exterior próximo. No capítulo final, se buscará explicar as perguntas levantadas acima com o levantamento do estudo de caso. 


\section{MARCO TEÓRICO}

Este capítulo irá abordar os conceitos teóricos que se entende ser os melhores para compreender a conjectura russa no atual cenário internacional. Nesse sentido se fará um resumo das correntes teóricas Realismo e da Geopolítica, o Eurasianismo. A primeira parte deste capítulo se abordará o pensamento russo em relação à sua identidade e como a busca por essa identidade se espelha na sua política externa também.

\subsection{RÚSSIA, OCIDENTAL, ORIENTAL OU ÚNICA?}

A Rússia é o maior país do globo em termos geográficos, é banhada por três oceanos: o Atlântico, o Ártico e o Pacífico. Um quarto de seu território está localizado na Europa, a outra parte na Ásia. Faz fronteiras com diversos países como: Finlândia, Polônia, os países Bálticos, Belarus, hoje denominado Bielorrússia, Ucrânia, também com os países do Cáucaso e Cazaquistão, Mongólia, China, Coreia do Norte, e fronteiras marítimas com Japão, Suécia e EUA (MINISTÉRIO DA EDUCAÇÃO E CIÊNCIA DA FEDERAÇÃO RUSSA, 2013). Mas afinal de contas, a Rússia é

Ocidental, Oriental ou única?

Pedro, o Grande (1672-1725) em suas viagens à Europa julgou o país atrasado em relação ao Ocidente, dessa forma anunciou seu objetivo de cortar os laços do povo com seus costumes asiáticos e ensinar como os ocidentais cristãos europeus viviam. Seguindo essa ideia, foi lançado uma série de decretos que faria com que a Rússia passasse a adotar cortes de cabelos ocidentais, buscaria conhecimentos tecnológicos nos moldes europeus e etc. (KISSINGER, 2015).

Antes desse período a Rússia tinha mais influência do lado oriental, das invasões mongóis, em que estes tinham o controle econômico russo, mas não a influência cultural ou religiosa. Também havia a influência de Bizâncio, essa sim com peso cultural, e depois do fim do cerco mongol, economicamente. Com as novas mudanças, Pedro, o Grande, abriu caminho para o mar no sul do país, no mar negro, onde tomou territórios dos turcos, e posteriormente, dos suecos no mar báltico. Dessa forma, criou uma marinha e um porto na cidade de São Petersburgo, uma cidade 
criada por Pedro em homenagem a São Pedro, mas de forma indireta, a si mesmo (SEGRILLO, 2012).

Catarina, a Grande (1762-1796), também fez parte dessa iniciativa de transformar a Rússia em um país totalmente europeu. Esta julgou necessário lembrar a seus súditos de que a "Rússia é um Estado europeu" (Catarina II apud Kissinger, 2015, p. 61).

Depois de Pedro, o Grande e Catarina II, a Grande, até 1815, a Rússia segue embalada em seu período de modernização. Na Guerra napoleônica e no congresso de Viena, a Rússia de Alexandre I (1801-1825) teve um peso importante neste momento, e assim, há um certo acomodamento em relação ao então desenvolvimento. $\mathrm{O}$ andamento da revolução industrial na Europa deu um embalo à modernização ocidental, mas a Rússia não seguiu o mesmo modelo, e somente na Guerra da Crimeia, no ano de 1853 a 1856, se percebeu que o país uma vez mais está atrasado, principalmente no quesito bélico, o que leva o país a buscar uma nova modernização. No período de Alexandre II, o Czar "Libertador" (1855-1881) se tem sua Reforma emancipadora, no que o curso de seu governo foi mais liberal e menos repressor, a Rússia sai de seu sistema semifeudalista, com a abolição da servidão, e passa para um sistema próximo ao capitalismo, com trabalho assalariado (SEGRILLO, 2012).

No século XIX, alguns pensadores se institucionalizaram como Ocidentalistas, enquanto outros, insistiam que a Rússia era um país único, diferente do Ocidente, e deveria seguir seu próprio caminho, os eslavófilos. E por volta do primeiro quarto do século XX, um novo pensamento, transverso, apareceu entre os emigrados russos, o de que o país era tanto europeu como asiático, os mesmos diziam que os russos estavam por formar uma grande etnia eurasiana, estes se denominaram os eurasianos (SEGRILLO, 2011).

Com o desmantelamento da URSS e a chegada de Yeltsin, se tem a busca de um alinhamento direto com o Ocidente. Não só o então Presidente, mas quase toda a classe dirigente do país entendia que o único caminho para o desenvolvimento seria o alinhamento direto com o Ocidente (PECEQUILO, 2012).

Dessa forma Andrei Kozirev assume a pasta dos Negócios Estrangeiros no início de 1992, seguindo com uma política de aproximação com o Ocidente, em que ele definia a Rússia como aliada natural da Europa (FREIRE, 2009). 
Com o descaso ocidental frente as crises na Rússia, assim, se buscaram uma reformulação deste pensamento em 1993. Dessa forma, a vizinhança próxima tornouse foco da política externa russa, tendência que se mantém até hoje (FREIRE, 2009).

Em 1995, Levgeni Primakov assumiu o Ministério dos Negócios Estrangeiros, este entendia que "a Rússia não tem inimigos permanentes, mas tem interesses permanentes" também seguindo a linha de descontentamento em relação ao Ocidente, principalmente em relação ao avanço da OTAN, Organização do Tratado do Atlântico Norte, percebendo-a como inimiga e contrarias aos interesses russos (FREIRE, 2009). Mesmo que Primakov tenha ficado pouco tempo na Chancelaria suas ideias seguiram na política russa e foram mais intensas no governo Putin (AMAL, 2017). Primakov também é visto com forte pensamento geopolítico Eurasianista, que será aprofundado adiante.

Segundo Segrillo (2011), Putin seria um ocidentalista moderado, porque depois dos anos 2000 o país não estava mais inabilitado economicamente, não necessitava mais um alinhamento direto com o Ocidente, como Yeltsin tentou. Destarte, Putin é moderado por vir depois de Yeltsin, seguir algumas políticas de alinhamento com Ocidente, mas com o país melhor economicamente, e com sua história de grande potência (período czarista) e superpotência (período soviético) é notável a buscar seus próprios interesses.

O mesmo o define ocidental moderado por questões políticas no sentindo de que Putin sabe que a população russa se mantém em um meio termo, nem extrema ocidentalista, nem extrema eslavófila, assim ele permanece pragmático na questão. Outro ponto que o autor menciona, é a de que Putin é um gosudarstvennik (defensor de um Estado forte). Dessa forma, quando este bate de frente com o Ocidente, apenas está defendendo os interesses russos. Quando o Ocidente tende a cooperar e a ser menos confrontador, a Rússia tende a cooperar, quando o Ocidente tende a confrontar, os aspectos estatistas, especialmente de Putin, fazem com que a Rússia parta para seus interesses nacionais, e assim o confronto com o Ocidente, afinal de contas, a Rússia não é antiocidental, somente defende seus interesses. Medvedev, por outro lado, estaria em um meio termo, não tão ocidentalista como Yeltsin, nem tão moderado como Putin (SEGRILLO, 2011). 


\subsection{O REALISMO}

O Realismo Político é umas das principais teorias das Relações Internacionais, e tem como cerne de seu estudo a questão do poder e do conflito, portanto, enxergando o mundo de forma anárquica, onde não há um poder coercitivo para controlar o sistema, destarte, os estados são independentes para fazer o que quiserem (PECEQUILO, 2012).

Os teóricos realistas surgem após o fracasso dos idealistas modernos no entre guerras, e buscam por meio de clássicos da política e filosofia, como O Príncipe, de Maquiavel, e O Leviatã, de Tomas Hobbes, formularem uma leitura realista das Relações Internacionais, produzindo o campo de estudo e a teoria realista, os primeiros modelos de entendimento por intermédio de fatos reais, em especial do internacional (PINTO, 2016).

Dois dos autores mais importantes do século XX são Edward Hallet Caar, que através de sua obra Vinte anos de crise, produziu uma dura crítica ao idealismo, e Hans Morgenthau com sua obra A política entre as nações: a luta pelo poder e pela paz, ocorrendo assim uma superação ao idealismo (PINTO, 2016).

O realismo parte da ideia de que os estados são atores racionais. No cenário de anarquia do sistema internacional, o Estado, sendo o principal ator, motivado pela preocupação de sua sobrevivência, busca um equilibro de poder, agindo, dessa forma, por meios de ações estratégicas (SILVA, 2010).

Para Pecequilo (2012) o equilíbrio de poder surge das ideias do Cardeal Richelieu, do que ele chamou de raison d'état, o conceito Razão de Estado, que estabelece que os interesses do Estado devem ser buscados racionalmente, ou seja, visando um cálculo de custos e benefícios, sendo julgado exclusivamente como critérios políticos, visando o incremento do poder nacional. No governo de Bismark foram chamadas de realpolitik. Dessa forma:

“Na Alemanha unificada de Bismarck (1815/1898), as práticas do equilíbrio de poder e a ação baseada em considerações racionais visando o interesse do Estado passam a ser definidas como Realpolitik" (PECEQUILO, 2012, p. 30).

Para Lacerda (2006) significa que:

Ele rege as relações entre as potências, estipulando que todas devem ter mais ou menos a mesma quantidade de poder, umas em relação às outras, de modo que se mantenha uma relativa paridade, que exista um certo equilíbrio entre todas (LACERDA, 2006, p. 62). 
Para os neorrealistas o conceito de equilíbrio de poder é:

Nota-se, então, que diferente do que coloca o realismo clássico, Waltz percebe que a política internacional é definida pelos constrangimentos estruturais. A estrutura do sistema faz com as ações gerem resultados inesperados. Por mais que os Estados não desejem viver em um ambiente hostil, eles precisam resguardar seus interesses. Se um Estado agir diferente, ele arcará sozinho com os prejuízos e isso não trará mudanças estruturais. A questão central da contribuição de Waltz, então, é que num ambiente anárquico, onde impera a autoajuda, os Estados tendem a buscar um equilíbrio de poder. Para sobreviver, os Estados contam com esforços internos, que podem ser traduzidos como o incremento das capacidades, e esforços externos, através da formação de alianças [...] A teoria do equilíbrio de poder, dessa forma, busca explicar um resultado que pode ser percebido no sistema: a formação de balanças de poder. Não se trata de discutir se o equilíbrio, uma vez alcançado, é mantido ou não. O ponto relevante é perceber que, uma vez que o equilíbrio tenha sido alterado, ele será restaurado de uma forma ou de outra. Isso ocorre porque o sistema estimula os Estados a buscarem segurança, induzindo ao equilíbrio. A principal preocupação dos Estados é, então, manter sua posição dentro do sistema, garantindo assim a sobrevivência (DUARTE, 2011 apud REIS, 2015, p. 19).

Na década de 1970 surge o Neorrealismo, porquanto as ideias realistas já eram contrarias às evidências empíricas na nova realidade (período da bipolaridade da Guerra Fria). Dessa forma, sofrendo muitas críticas dos liberais e globalistas. Nesse sentido surgem novos autores buscando atualizar o pensamento realista principalmente no aspecto econômico. Os principais autores do Neorrealismo são: Robert Keohane e Joseph Nye (LACERDA, 2006).

Para este artigo, os conceitos de Nye sobre o poder brando, soft power e poder duro, o hard power são de maior importância. Estes conceitos têm base da distinção entre a baixa e alta política, ou low and high politics, emergido no cenário europeu. Para Pecequilo:

A distinção entre a baixa e a alta política (low and high politics) também emerge no cenário europeu, identificando as esferas da economia e da cultura (low) e da diplomacia, do poder e da guerra (high). No período contemporâneo, estas classificações são intercambiáveis com as perspectivas do poder brando e duro, podendo ser percebida a variação em seu peso ao longo dos séculos. Para a consolidação do Estado, o poder duro estava no núcleo das preocupações, mas com a evolução de suas dinâmicas e a maior complexidade do cenário, o brando ganhou espaço, superando a condição secundária da baixa política (reconhecendo a multidimensionalidade do poder) (PECEQUILO, 2012).

\section{Dougherty e Pfaltzgraff enfatizam os seis principais componentes} compartilhados pelas visões realistas:

[...] (1) o sistema internacional é baseado no Estado-Nação como seu atorchave (2) a política internacional é essencialmente conflituosa, uma luta por poder em um ambiente anárquico no qual estes Estados inevitavelmente dependem de suas próprias capacidades para garantir sua sobrevivência (3) os Estados existem em uma condição de igualdade de soberania, porém 
detêm diferentes capacidades e possibilidades (4) os Estados são os atores principais e a política doméstica pode ser separada da política externa (5) os Estados são atores racionais, cujo processo de tomada de decisão é sustentado em escolhas que levem à maximização de seu interesse nacional (6) o poder é o conceito mais importante para explicar e prever o comportamento dos Estados (DOU-GHERTY; PFALTZGRAFF apud PECEQUILO, 2012, p. 58).

\subsection{TEORIAS DA GEOPOLÍTICA CLÁSSICA}

No século XIX surge, com as necessidades da revolução industrial acontecida do século anterior, a promoção do colonialismo, e a formação da grande Alemanha Imperial, tendo a necessidade de se expandir além de suas fronteiras após a unificação dos estados germânicos sob a coroa da Prússia, de Bismark, surge Friedrich Ratzel (1844-1904) com a obra Politische Geographie (1897) como o pai da Geopolítica (CHURRO, 2013).

Para Ratzel o Estado é visto como um organismo que vive, próspera, decai e morre. Nesse sentido, para o autor, o futuro político do Estado depende de seu espaço e sobretudo, de suas posições geográficas, que mantêm as relações entre os povos (REIS, 2015).

Nesse pensamento Ratzel afirma:

As fronteiras não são concebidas senão como a expressão de um movimento orgânico ou inorgânico; as formações estatais elementares assemelham-se, evidentemente, a um tecido celular: em tudo se reconhece a semelhança entre as formas de vida que surgem da ligação com o solo (RATZEL, 1987 apud BRAGA, 2011, p. 147).

Além de Ratzel, há duas outras teses importantes para a compreensão do pensamento geopolítico clássico, a tese do poder marítimo do almirante norteamericano Alfred T. Mahan anterior a Ratzel, de 1890, e a tese do poder terrestre, de Halford Mackinder de 1904.

\subsubsection{Teoria do Poder Marítimo}

Paul Claval (apud BRAGA, 2011, p. 148) infere que "os primeiros grandes debates geopolíticos referem-se ao papel do mar no progresso e na supremacia dos países anglo-saxões" assim, os debates dados neste contexto histórico eram referentes à expansão dos EUA, período em que os EUA adquiriram o Alasca, então da Rússia, e entrou em guerras contra a Espanha por territórios marítimos como: Cuba, Havaí e Filipinas (Braga, 2011). 
Seguindo esse pensamento em 1897 Mahan publica The interest of America in sea power, uma obra em que ele define as doutrinas que seu país deve seguir, com três aspectos bases para o desenvolvimento de um país que enseje ser uma potência: econômico, militar e geopolítico (REIS, 2015).

O Aspecto econômico é baseado na capacidade de produção e a capacidade comercial, o aspecto militar é baseado na capacidade da força marítima que para o autor é fundamental para qualquer Estado que tenha aspiração de ser uma potência, e por fim, no aspecto geográfico, o autor considera como fundamental questões de posição geográfica, o espaço territorial, população, a capacidade que o pais tem de expansão comercial, e um governo com afetos para o domínio do mar (REIS, 2015).

Mahan baseava sua ideia de poder marítimo em um conceito simples, se o globo é composto por quase $70 \%$ de áreas marítimas, quem tivesse o controle dos mares teria um poder inigualável (CHURRO, 2013).

\subsubsection{Teoria do poder Terrestre}

Mackinder, apesar de não usar o termo geopolítica, pois preferia mais o termo geografia política, é considerado um dos principais teóricos das teorias globais de poder. Ele tinha uma abordagem diferente de Mahan, dando mais importância ao poder terrestre em face ao marítimo (CHURRO, 2013). Em sua teoria apresentada no trabalho The Geographical Pivot of History de 1905, criou os conceitos de Heartland, o coração da terra e da llha Mundial (REIS, 2015).

Mackinder classificou o mundo em duas regiões geográficas e fundamentais. A primeira delas é a llha Mundial, esta corresponderia à Europa, Ásia e a África, região em que teria ocorrido a maiorias dos eventos e guerras mais importantes da história. A outra região, que é o restante do mundo, ele chamou de llhas do Exterior. O Heartland, seria a área pivô, sendo o centro da llha Mundial, referente ao território eurasiático (REIS, 2015).

Para Mackinder, o território euroasiático, o Heartland, que corresponde ao território Czarista, com riquezas em diversos recursos, permite ao Estado que controlar essa região ter o desenvolvimento de um grande poder, dessa forma, o mesmo afirma que "Quem domina a Europa Oriental controla o Heartland; quem domina o Heartland controla a World Island; quem domina a World Island controla o mundo" (MACKINDER, 1919 apud BRAGA, 2011). 
"Quem controla a Europa Oriental, domina a Heartland; quem controla a Heartland, domina a Itha Mundial; e quem controla a ltha Mundial, domina o Mundo".

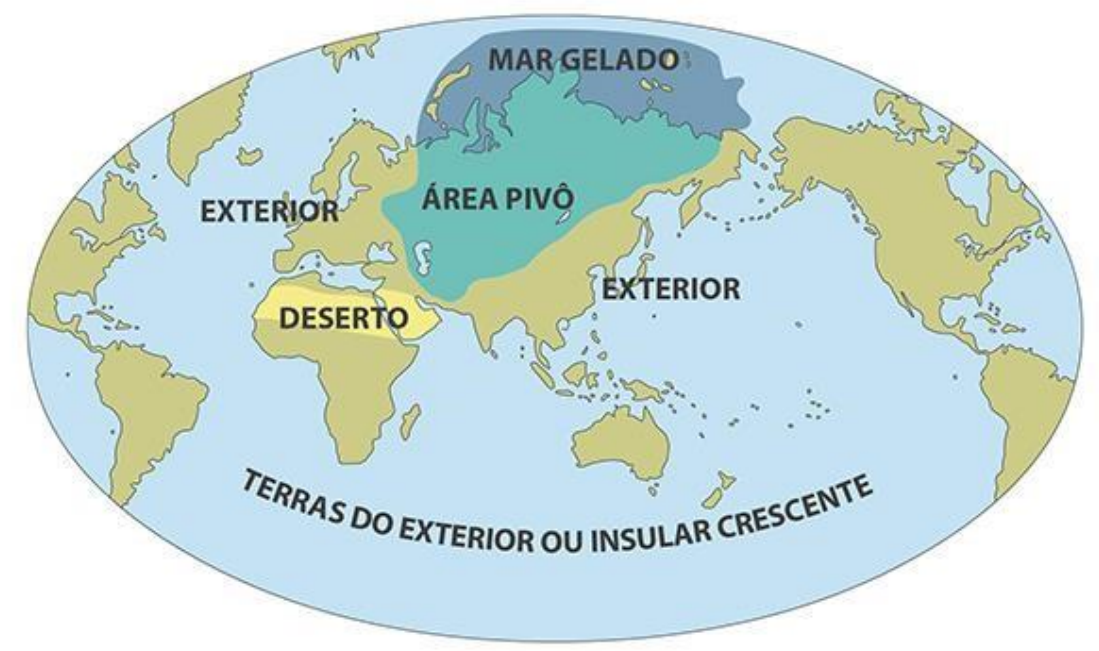

Proposiçāo de Halford Mackinder sobre a Heartland (ou área pivô)

Fonte: Universia 2018.2 Disponível em: <http://www.universiaenem.com.br/sistema/faces/pagina/publica/conteudo/textohtml.xhtml?redirect=2 7663428230511852530356729621 >. Acesso em: 12 set. 2018.

\subsubsection{A teoria das Pan-Regiões}

Segundo o pensamento de Mackinder, Selon Haushofer também dividiu o mundo em quatro regiões, as Pan-Regiões, em sua obra de 1931, Geopolitik der Panldeen, todas elas autossuficientes em população, recursos e acesso ao Mar (CHURRO, 2013).

O principal objetivo desta obra era manter um possível equilíbrio entre as grandes potências mundiais satisfeitas com seus respectivos territórios de domínio, dessa forma:

Esta espécie de "Tratado de Tordesilhas versão séc. XX" não era, no entanto novidade, na medida em que o próprio Mackinder já tinha proposto algo semelhante. Na sua base de funcionamento, cada uma das Pan-Regiões seria dirigida por um Estado mais forte e desenvolvido económica e militarmente que tinha o dever de garantir o desenvolvimento dos restantes Estados que estavam na sua órbita (CHURRO, 2013 p. 35).

Estas zonas são: Zona Anglo-Americana, liderada pelos EUA (e suas possessões no Pacífico), que compreende as Américas, pelas llhas Britânicas, pela Austrália e Nova Zelândia; Zona Euro-Africana, liderada pelos principais países do que hoje compreende a União Europeia, Alemanha e França. Corresponde a quase todo 
o território Europeu, sem os Países Bálticos, e ainda com todo o continente africano e a Península Arábica; a Zona Pan-Eurasiana, esta liderada pela Federação Russa, compreendendo todos os países da Comunidade dos Estados Independentes, a CEI, a Mongólia, a Península Balcânica, Turquia, Irã, Paquistão, Índia e os outros países da Ásia Meridional; e a Zona do Pacífico, liderada pela China e que compreenderia com o extremo oriente da Ásia (Japão, Taiwan e as Coreias) e o Sudeste Asiático com mais algumas nações da Oceania (PEREIRA, [2010?]).

Figura 2 - As Pan-Regiões

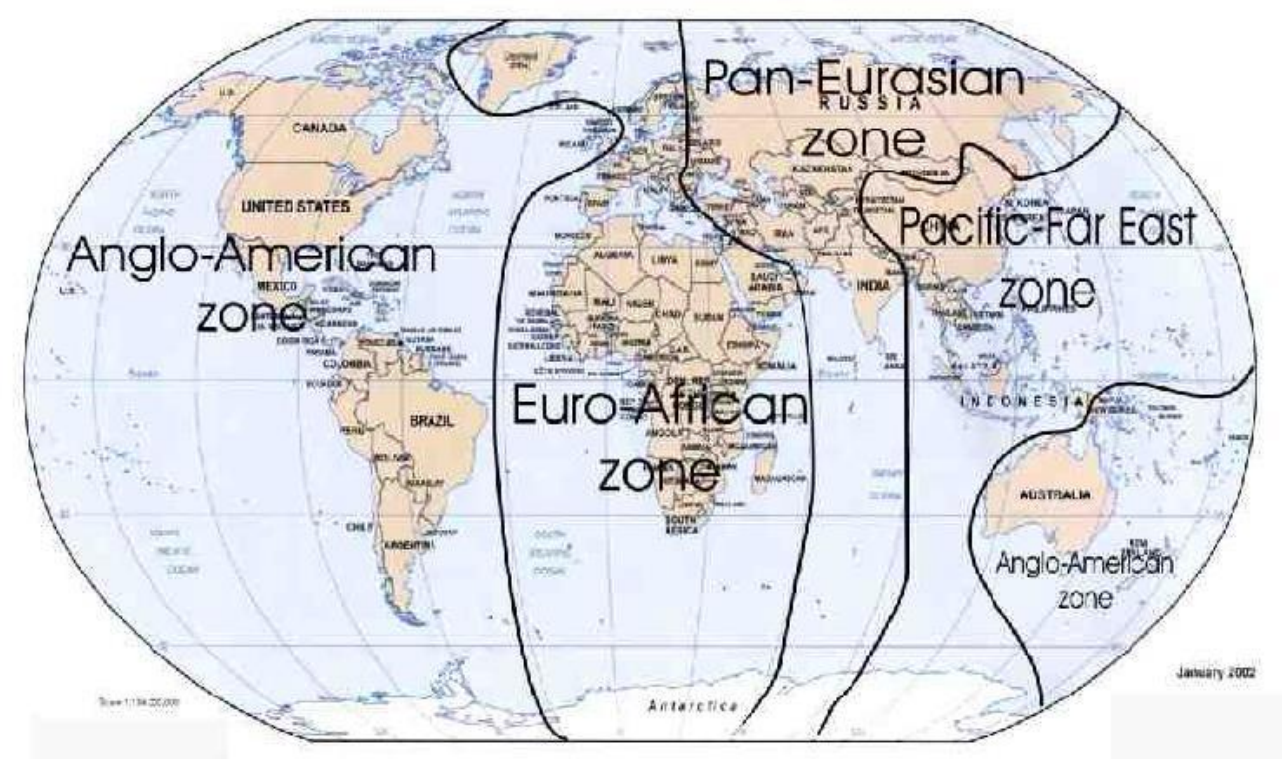

Map of mullipolar wo-ld. Four zones - iour poles

Fonte: Danilo R. Sousa, 2012. Disponível em: <https://www.researchgate.net/figure/Figura-2-Omundosegundo-os-eurasianistas_fig2_261301541>. Acesso em: 31 set. 2018.

\subsection{O EURASIANISMO: OS OCIDENTALISTAS, OS EXPANSIONISTAS E O NEOEURASIANISMO NA ATUAL CONJECTURA RUSSA}

Em 1991, com o fim da União das Repúblicas Socialistas Soviéticas, tem-se um vácuo geopolítico no espaço de influência da Rússia, assim, o país precisou se reposicionar no cenário geopolítico, pois os antigos aliados estavam passando para a influência geopolítica do Tratado do Atlântico Norte, a OTAN, com exceção da Bielorrússia e Ucrânia, esta última com receio de uma divisão no país, pois a parte oriental é muito russificada (SOUSA, 2012).

A Rússia como herdeira do legado soviético buscou manter ao menos em um mínimo possível, sua esfera de influência nessa região, com a criação da Comunidade dos Estados Independentes, a CEI, em 1992 (PEREIRA, [2010?]) e com a chegada 
de Putin, com a União Econômica Eurasiana em 2000 (VISENTINE, 2015). No âmbito desse pensamento, durante os anos 1990 surgem duas correntes de pensamentos, os ocidentalistas e os eurasianistas (PEREIRA, [2010?]).

\subsubsection{Os ocidentalistas}

Os ocidentalistas, formados por acadêmicos de pensamentos idealista-liberal, creem que a Rússia deve buscar uma maior cooperação com o Ocidente, buscar uma modernização e sua integração à globalização, ensejando os valores euro-americanos para ter maior protagonismo no sistema internacional. Este grupo também percebe a aproximação com os países islâmicos e as antigas repúblicas soviéticas da Ásia Central com desconfiança e uma grande ameaça à segurança russa. Os mesmos também acreditam que a Rússia é uma ponte entre o Ocidente e o Oriente (PEREIRA, [2010?]).

\subsubsection{Os eurasianistas}

O Eurasianismo surge em início do século $X X$, elaborado por um grupo de intelectuais exilados que viam a Revolução Russa como uma transição necessária para modernizar um país atrasado, e depois desta revolução voltariam a ser um Estado tradicionalista, confessional e acima de tudo, nacionalista. Não acreditavam na Rússia como Ocidental, mas juntos com os cristãos ortodoxos, os eslavos, romanos e gregos, e com os muçulmanos, formariam a Eurásia, um espaço euroasiático (FLORETIN, 2014).

Esse pensamento político parte da ideia de Mackinder, com a ideia do Heartland, de que quem domina o Heartland domina o mundo, especialmente se controla a Ucrânia, (por sua importância geográfica citada em capítulo seguinte deste trabalho) (FLORETIN, 2014). O mesmo também afirma que a geopolítica vive de um confronto de potências terrestres os continentalistas e as potências marítimas, as atlantistas (SOUSA, 2012).

Esse movimento pode ser explicado também na questão identitária russa do Pan-eslavismo, citado acima, que sempre esteve presente no povo russo, nesse sentido, seria o "destino manifesto" da Rússia, recuperar os territórios que fizeram parte da URSS e os do Império Russo (SILVA, 2010). 
Estas ideias perderam força nos anos de 1930, mas hoje a escola Eurasianista tem como seu principal instrutor Aleksander Dugin, professor da Universidade Estatal de Moscou e o Instituidor do Movimento Eurásia, uma estrutura que defende as tradições culturais russas em contraposição aos valores ocidentais manifestados na globalização (PEREIRA, [2010?]).

Dentro da corrente política eurasianista há duas subdivisões, uma delas são os realistas, estes notadamente compostos pelos antigos membros intelectuais do PCUS, Partido Comunista da União Soviética. Acreditam no poder como instrumento para a busca de controle e equilíbrio, em detrimento da cooperação internacional, nesse sentido, creem que a Rússia deve continuar desenvolvendo seu poderio militar e nuclear, para assim, equilibrar a balança de poder internacional contra o Ocidente.

Para Teixeira:

Esta corrente de pensamento percebia o ambiente externo hostil aos interesses russos e que a dissolução da URSS foi consequência das ações premeditadas e bem planejadas pelo mundo ocidental (TEIXEIRA, 2008 apud SOUSA, 2012).

Para Silva, (2010), o pensamento realista russo é dividido entre defensivo e ofensivo. Defensivo pois sabe da sua debilidade em enfrentar os EUA sozinho, e ofensivo contra a periferia, como no caso da Geórgia, onde agiu com força pois se tinha em conta a fragilidade do país e a não intervenção do Ocidente. Nesse sentido, se pode conjecturar a ação da Rússia na Crimeia neste mesmo pensamento.

A outra subdivisão da corrente eurasianista são os eurasianistas expansionistas, ou revolucionários, que representam os ultranacionalistas de extrema direita. Da mesma forma que os realistas defendem a competição e a expansão e as relações de poder no cenário internacional, eles acreditam que a Rússia necessita de mecanismos para se reafirmar no sistema caótico internacional, sendo que sua reafirmação é determinante para sua segurança (PEREIRA, [2010?]).

O nome mais importante para a corrente eurasianista é Aleksander Dugin, cujo pensamento é bem alinhado com a política externa russa.

Quando Putin assume o poder, Aleksander Dugin percebeu a materialização do eurasianismo em Putin. Em 2007, Dugin foi expulso da Ucrânia por fomentar a separação entre os cidadãos russos no país. Foi o primeiro a anunciar que a Rússia interviria na Ossétia do Sul, o que rapidamente aconteceu. Nas mobilizações de 2008, os militantes do movimento eurasiático foram às ruas em apoio à Putin. Dessa forma, se percebe um alinhamento da política externa do governo russo com o teórico. A CEE tem forte fundamento nestas ideias (FLORETIN, 2014). 
O neoeurasianismo, como é chamado hoje o movimento que teve suas estruturas ensejadas no início do século XIX, é um projeto estratégico, geopolítico e de integração econômica do norte do espaço eurasiano. Dessa forma, se busca na nova Rússia, a construção de um Estado multiétnico e multireligioso, se vê a necessidade de promover alianças externas e reforçar o estabelecimento dos eixos geopolíticos estratégicos, como os de Berlim-Moscou, Moscou-Teerã e MoscouPequim (SOUSA, 2012).

O neoeurasianismo nega o sistema globalizado e o sistema universal do Atlanticismo, visam proteger, segundo Dugin, a diversidade dos valores russos e os do mundo. Assim, o neoeurasianismo nega um universalismo dos valores democráticos e do liberalismo, advogando uma ideia do mundo multipolar (SOUSA, 2012).

Aleksandr Dugin, em sua Teoria do Mundo multipolar, traz a globalização como uma imposição do paradigma atlântico. Para ele a globalização é unilateral, e pretende universalizar o pensamento de uma das civilizações afim de destruir as demais civilizações, e os seus valores. Nesta teoria, se apresenta também as civilizações divididas em quatro zonas geográficas, as mesmas citadas acima, as zonas das Pansregiões (REIS, 2015).

Nesse sentido, em 2001, a Rússia funda em conjunto com a China e os quatro países da Ásia Central (Cazaquistão, Uzbequistão, Quirguistão e Tadjiquistão) a Organização para Cooperação de Xangai, que é uma reestruturação da organização Os Cinco de Xangai, de 1996. Desde sua criação tem expandido sua relevância regional para se tornar foco de considerável importância no jogo geopolítico da eurásia (VISENTINE, 2015).

Para Pereira:

[...]é evidente que a Rússia está diante de uma nova realidade geopolítica. Seus antigos aliados e pensamentos ideológicos da era comunista, já não existem mais, e em seu entorno estratégico há uma nova configuração de poder geopolítico, com a atração de atores externos e reavivamento de animosidades. A Organização de Cooperação de Shangai talvez seja o grande constructo institucional dessa realidade, uma forma de Moscou buscar sua reafirmação como potência nessa nova conjuntura. $O$ Eurasianismo emerge em uma Nova Rússia em um momento de ressurgimento geopolítico, econômico e estratégico, e provavelmente é a corrente teórica-geopolítica mais presente em sua conduta política externa. As influências de autores geopolíticos e realistas na construção do pensamento russo é notável, e o Eurasianismo os canalizou em suas proposições. Se a Rússia voltará a ter o peso geopolítico que tinha a antiga superpotência soviética ainda é incerto, porém, os mecanismos criados nos mandatos de Putin e Medvedev contribuíram e muito para retornar o 

[2010?]).

Dessa forma, se percebe a influência deste pensamento político na nova política russa na virada do século. Primeiramente a tentativa de se alinhar e de buscar uma integração com o Ocidente, no início da década de 1990, tendo a não aceitação que buscava, já da metade dos anos de 1990, com Primakov se tem uma busca por uma política mais eurasianista, que foi intensificada no governo Putin.

Em uma visão realista, dentro ainda do pensamento geopolítico se tem um realismo assertivo, em momentos usando o soft power, em outros o hard power. $\mathrm{O}$ soft nos âmbitos dos órgãos como a CEI, UEE e OCX, em que a Rússia busca manter uma influência de forma mais branda, ou em momentos em que o soft power não foi suficiente, se teve o uso da força, como no caso da Geórgia e Ucrânia (FREIRE, 2008).

\section{DA URSS À RÚSSIA}

A URSS, depois da Segunda Guerra Mundial junto dos Estados Unidos, alcançou o status de superpotência, fato inédito na história das Relações Internacionais. Todavia, nas décadas dos anos de 1960 e 1970, a URSS começou a se desestabilizar levando ao seu fim em 1991. O capítulo está focado nessa dimensão.

No período entre guerras, e sobretudo na década de 1930 época da grande depressão no Ocidente, o crescimento da economia soviética esteve mais elevado que a de todos os outros países, menor apenas que a do Japão. Prontamente, nos quinze anos depois da Segunda Guerra, as economias de todo o campo socialista cresciam mais rápido que as do Ocidente (HOBSBAWAN, 1995). Com relação aos EUA, nas décadas de 1930 a 1950, a URSS estava crescendo três vezes mais rápido (SEGRILLO, 2012). 
Tabela 1 - Taxas de Crescimento Econômico Anual da URSS

TABELA: TAXAS DE CRESCIMENTO ECONÔMICO ANUAL DA URSS, 1928-1991, SEGUNDO AS ESTATISTICAS OFICIAIS

(PERCENTAGEM DE CRESCIMENTO ANUAL DO PRODUTO MATERIAL LIQUUIDO*)

\begin{tabular}{|c|c|c|c|c|c|c|c|c|c|c|c|c|c|}
\hline Ano & 1928 & 1929 & 1930 & 1931 & 1932 & 1933 & 1934 & 1935 & 1936 & 1937 & 1938 & 1939 & 1940 \\
\hline$\%$ & 8,2 & 16,0 & 21,0 & 16,8 & 11,3 & 6,5 & 15,2 & 19,2 & 29,3 & 12,0 & 8,9 & 9,5 & 11,6 \\
\hline Ano & 1941 & 1942 & 1943 & 1944 & 1945 & 1946 & 1947 & 1948 & 1949 & 1950 & 1951 & 1952 & 1953 \\
\hline$\%$ & -8 & $-28,3$ & 12,1 & 18,9 & $-5,7$ & -6 & 19,1 & 24,1 & 18 & 20,1 & 12,2 & 10,9 & 9,8 \\
\hline Ano & 1954 & 1955 & 1956 & 1957 & 1958 & 1959 & 1960 & 1961 & 1962 & 1963 & 1964 & 1965 & 1966 \\
\hline$\%$ & 12,0 & 11,9 & 11,4 & 6,7 & 12,6 & 7,4 & 7,7 & 6,9 & 5,6 & 4,1 & 9,4 & 6,8 & 8,0 \\
\hline Ano & 1967 & 1968 & 1969 & 1970 & 1971 & 1972 & 1973 & 1974 & 1975 & 1976 & 1977 & 1978 & 1979 \\
\hline$\%$ & 8,7 & 8,3 & 4,7 & 9,1 & 5,6 & 3,9 & 8,9 & 5,4 & 4,5 & 5,2 & 4,5 & 5,1 & 2,2 \\
\hline Ano & 1980 & 1981 & 1982 & 1983 & 1984 & 1985 & 1986 & 1987 & 1988 & 1989 & 1990 & 1991 & \\
\hline$\%$ & 3,9 & 3,3 & 4,0 & 4,2 & 2,9 & 1,6 & 2,3 & 1,6 & 4,4 & 2,5 & -4 & -9 & \\
\hline
\end{tabular}

Fontes: Bol'shaya Sovetskaya Entsiklopediya ["Grande Enciclopédia Soviética"], 2. ed., v. 29, p. 302; Narodnoe Khozyatistvo SSR - Statisticheskii Ezhegodnik [“A Economia da URSS - Anuário Estatístico"], diversos anos, e site do Rosstat ["Serviço Federal de Estatistica do Estado"].

Fonte: Segrillo, 2012, p. 235.

Esse bom momento da URSS fez com que muitos acreditassem fielmente na superação do sistema socialista frente ao capitalismo. Líderes soviéticos, citando caso análogo, como Nikita Kruschev, acreditava veemente que isso seria possível. Levando em consideração os crescimentos elevados até então, o socialismo iria superar o capitalismo em produção em um futuro próximo (HOBSBAWAN, 1995).

Todavia, a partir de 1960 já se percebia o declínio econômico da URSS. Nos anos 1950 , o crescimento estava em torno de $5,7 \%$. Nos anos 1960 se reduziu a 5,2\%, caiu para $3,7 \%$ nos anos de 1970 , e de 1980 a 1985 chegou ao nível médio de $2 \%$ (VERGOA, 2005).

Para Hobsbawan (1995) o início do desmoronamento político da URSS, começou com a morte de Stalin em 1953, mais precisamente em 1956, no XX Congresso do Partido Comunista da União Soviética (PCUS). Por motivos de ataques à era stalinista e mais ainda ao próprio Stalin, por parte da alta cúpula do Partido Comunista.

No XX Congresso do PCUS, Nikita Kruschev (1953-1964), então Secretário do partido, fez um discurso onde denunciou as violências, os expurgos e todas as atrocidades cometidas por Stalin. O objetivo seria uma tentativa de deixar de cultuar a imagem de Stalin (SEGRILLO, 2012). 
Dessa forma, com estas atitudes, no fim da década de 1950 a China rompe relações com a URSS, pois a China agora questionava a liderança da URSS no movimento comunista internacional (HOBSBAWAN, 1995). Tais atitude fizeram com que a China visse a URSS saindo do revolucionário pensamento Socialista.

Em meio a estas dificuldades políticas, os efeitos na parte europeia, que era dominada pela URSS, foram logo sentidos. Na Polônia houve uma mudança para uma liderança comunista reformista, o que foi aceito pela URSS. E houve uma revolução na Hungria. Liderada por Imre Nagy, outro comunista reformista, o qual anunciou o fim do sistema uni-partidarista e tirou a Hungria do Pacto de Varsóvia, o qual não poderia ser aceito pela URSS. Destarte, em novembro de 1956, a revolução foi reprimida pelos soviéticos (HOBSBAWAN, 1995).

Também neste mesmo contexto, a lugoslávia de Tito, até a Primavera de Praga, optara por neutralidade, enquanto a Albânia saia da zona de influência da URSS e passaria para a da China (SEGRILLO, 2012).

Para Hobsbawan, outra desvantagem do sistema:

[...]e que acabou por afunda-lo, era sua Inflexibilidade. Estava engendrado para o crescimento constante na produção de bens cujo caráter e qualidade haviam sido predeterminados, mas não tinha qualquer mecanismo interno para variar quantidade (a não ser para cima) e qualidade, nem para inovar (HOBSBAWAN, 1995, p. 375).

O principal problema era que havia muito excesso da centralização, e que se completava com falta de estímulo para a criatividade individual, decerto se buscava somente cumprir os protocolos. Nesse contexto, com Leonid Brezhnev (1964-1982), em 1965, se tem reformas bem radicais não muito conhecidas, são as Reformas de Kosygin, pois foram levadas a cabo pelo primeiro ministro Aleksei Kosygin (SEGRILLO, 2012).

Nestas reformas se tinha como objetivo dar autonomia às empresas para que estas desenvolvessem novas maneiras de produção mais criativas. Para forçar uma melhor quantidade do produto vendido, se mediria a quantidade de produto vendido, não a que foi produzido (antes a preocupação era somente em produzir e estocar), assim teria que se produzir melhor o produto para que este fosse vendido e não estocado como uma peça de má qualidade (SEGRILLO, 2012).

Nas palavras de Vengoa:

[...]una reforma administrativa que otorgaba mayor cobertura de acción e independencia a las empresas, la disminución de los índices ejecutivos a partir del plan, la reforma de los precios y la aplicación de nuevos criterios de performance en la realización de la producción, los cuales contemplaban la introducción del beneficio en el funcionamiento de la economia soviética (VENGOA, 2005, p. 168). 
O problema encontrado nesta reforma foi que, como o regime era baseado num poder central forte, muito burocrático, houve implicações quando condutores locais começavam a querer implementar ideias que tinham como boas, mas não eram aceitas pelos planejadores centrais (SEGRILLO, 2012).

Para Hobsbawan (1995), um dos fatores em relação à administração soviética que se tem que levar em conta é a questão da burocracia. Já no período de Stalin, se tinha muitas dificuldades neste sentido, onde este tinha que lutar para "superar o labirinto burocrático e sua habilidade em esquivar-se da maioria dos controles e ordens do governo" (LEWIN,1991 p, 17 apud HOBSBAWAN, 1995, p. 374). Para o autor, depois de Stalin e Kruschev, não havia mais nada que pudesse parar a estagnação.

Segundo Vengoa (2005), as magnitudes das relações intra-burocráticas eram tão grandes que não seria exagero dizer que o partido já não detinha e nem realizava o poder nesta área. Dessa forma, a reforma, mesmo com seu início eficiente, se esvaia cada vez mais, até seu fim no início da década de 1970.

Nesse sentido se pode entender porque em agosto de 1983, com uma resolução oficial, Yuri Andropov (1982-1984), o sucessor de Brezhnev, tentou reconstruir o poder do partido em relação às burocracias. Onde o mesmo afirma:

\footnotetext{
Las asambleas electorales del Partido obedecen a un escenario establecido de antemano, sin debates serios y francos. Las profesiones de fe de los candidatos están listas para la publicación; toda iniciativa o crítica es ahogada. De ahora en adelante, nada de eso será tolerado (ANDROPOV apud VENGOA, 2005 p. 179).
}

Entretanto, com a morte Andropov e com a chegada de Constantin Chernienko (1984-1985) foi uma tentativa falida de reverter a situação.

Ademais, a estas questões políticas e da forma de condução da produção da URSS, outro fator que pôde ter tido um grande peso, foi a corrida armamentista em toda a Guerra Fria contra os EUA.

Após a primeira explosão da bomba atômica da URSS em 1949 começou uma corrida tecnológica pelas armas mais avançadas. Depois deste evento, se levou a cabo as guerras quentes localizadas na periferia do globo, ou como chamado, o terceiro mundo, apoiadas pelas duas superpotências. No fim dos anos 1960 fora adotada a Doutrina Brezhnev, que afirmava que a instabilidade política em um país socialista seria considerada uma instabilidade política na própria URSS, justificando assim uma intervenção militar (MEDEIROS, 2011). 
O ano de 1979 pode ser considerado vital para a virada de rumo da Guerra Fria. Dois fatores importantes, a Revolução Iraniana e a invasão da URSS no Afeganistão, faz com que os EUA intensifiquem o conflito com os soviéticos (MEDEIROS, 2011). O Irã agora sairia da zona de influência norte-americana e passaria a aproximar-se da URSS. Vale ressaltar a crise dos reféns americanos em Teerã. O Oriente Médio na década seguinte seria uma região instável, com as guerras Irã-Iraque e Guerra Civil no Líbano. Assim os EUA tentam intervir na região.

Reagan também usou da Intervenção da URSS no Afeganistão como forma de desgaste contra o Exército Vermelho, construindo uma diplomacia juntando os Muçulmanos ao pensamento Ocidental contra a intervenção. E no seu segundo mandato apoiou aos guerrilheiros com armamentos. O Afeganistão se transformou no Vietnã Soviético. Dessa forma, estas políticas custaram bilhões à URSS, enfraquecendo sua economia (MEDEIROS, 2011).

Para Kissinger (2015), Reagan foi de importância fundamental no fim da Guerra Fria. Pois ele liderou os EUA numa corrida armamentista em que a URSS não poderia competir, tomando como base programas parados no congresso, o que veio a ser chamado de Iniciativa de Defesa Estratégica. Comumente conhecido como o programa das Guerras nas Estrelas.

Os gastos com armamentos na URSS aumentavam de ano em ano de 1964 a 1984 em média de 4\% a 5\%. O que levou a uma situação insustentável, e em início dos anos 1980, 25\% dos gastos públicos eram relacionados à defesa (VENGOA, 2005).

Em meio a estas situações, em 1985, chega ao poder Mikhail Gorbachev (1985-1991). Uma jovem liderança comparada aos seus anteriores. Gorbachev tentou alterar a situação crítica da URSS com suas reformas muito bem conhecidas, a Perestroika, Reestruturação, e a Glasnost, Transparência.

$\mathrm{Na}$ Perestroika, o objetivo principal não fugia muito as políticas feitas no período de Brezhnev. Assim, também a Perestroika tentava dar mais autonomia as empresas estatais no planejamento central, ajudando assim, na difusão mais rápida de novas tecnologias e dos padrões de consumo (MEDEIROS, 2011).

Nas palavras de Gorbachev, as necessidades da Perestroika se davam devido:

O país começou a perder impulso. Os insucessos econômicos eram mais frequentes, as dificuldades começaram a se acumular e deteriorar, e os problemas não solucionados multiplicaram-se [...] formou uma espécie de freio que afetou o desenvolvimento socioeconômico. E tudo isso aconteceu 
numa época em que a revolução cientifica e tecnológica abria novos horizontes para o progresso econômico (GORBACHEV, 1987, p. 17).

E seu objetivo principal era:

A reforma tem como base a ampliação considerável da independência das empresas e associações, sua transição para o sistema de total autocomputação, de custos e autofinanciamento e a concessão de todos os direitos apropriados aos coletivos de trabalho. De agora em diante eles serão totalmente responsáveis por uma administração eficiente e resultados finais. Os lucros dos coletivos, ou seja, das unidades de trabalho, serão diretamente proporcionais à sua eficiência. [...] Liberaremos a administração central das empresas, e ela poderá concentrar-se nos processos chave para determinar a estratégia do crescimento econômico [...] A finalidade desta reforma é garantir [...] a transição de um sistema de direção excessivamente centralizado e dependente de ordens superiores para um sistema democrático baseado na combinação de centralismo demográfico e autogestão (GORBACHEV, 1987, p. 34-35).

A Glasnost por outro lado, visava diminuir a censura e a repressão política. Nessa nova conjectura a opinião pública pôde se politizar, tomando dessa forma, o conhecimento necessário dos males que atacavam a sociedade, igualmente, tiveram ciência dos altos níveis de corrupção do partido (VENGOA, 2005).

Seguindo essa linha, Gorbachev libertou presos políticos, deu liberdade à imprensa, deu liberdade para eleições no legislativo, além do mais, pela primeira vez, permitiu que outros partidos políticos concorressem à eleição. $O$ povo aceitou bem a abertura democrática, mas por outro lado, as reformas para introduzir a economia de mercado tardaram a surtir efeito. Com isso, houve o aumento de preço, racionamento, grandes filas, o que gerou uma grande rejeição a Gorbachev (MAX SEITZ, 2016).

Dessa forma, alguns membros do partido fizeram críticas mais duras as reformas, onde enfatizavam que as reformas não traziam melhorias econômicas e que estava pondo em risco todo o sistema, destarte, seria melhor parar com as reformas. Houve uma divisão de dois grandes grupos, de um lado os mais liberais e de outro os mais conservadores.

Em 1990 Boris Yeltsin foi eleito Primeiro Ministro da República Soviética Federada Socialista Russa. Anunciou resistência à Perestroika, e que a mesma seria combatida popularmente. Em março de 1991 em referendum, foi dado autonomia às demais repúblicas (MEDEIROS, 2011).

Em agosto de 1991, descontentes com todas as reformas de Gorbachev, e os rumos que a URSS seguia, os linhas duras do partido tentaram forçar um golpe. No dia 19 deste mês, a polícia da KGB (polícia secreta da URSS) cercou a casa de 
Gorbachev, enquanto seu vice, Gennady Yanayev, anunciou seu afastamento decretando assim estado de emergência (FIM... 1991).

O golpe de Estado, no entanto, ajudou a acelerar o processo, pois fracassou, e quando Gorbachev volta ao poder, há um novo herói, Boris Yeltsin, que desde o início organizara os movimentos de resistência popular. "Foi o começo do fim do comunismo na União Soviética e, talvez, da própria União Soviética. Hoje uma bandeira russa tremulava no Kremlim pela primeira vez desde 1917" disse Pedro Bial, em sua cobertura diretamente do Kremlim, já preludiando o Fim da URSS (FIM... 1991).

Em 8 de dezembro de 1991, a Rússia, a Ucrânia e a Bielo-Rússia, que juntas correspondiam a $70 \%$ da população soviética e por grande parte da riqueza do país, anunciaram a criação da Comunidade dos Estados Independentes (CEI). Com a aprovação pelo parlamento russo à adesão à $\mathrm{CEI}$, em 12 de dezembro daquele mesmo ano, seria questão de tempo, Gorbachev anunciar sua renúncia (FIM... 1991).

Com isso então, se tem as negociações do fim da URSS. No dia 26 de dezembro de 1991, um dia depois de Gorbachev renunciar, se dá por extinta a URSS em uma votação por membros do parlamento soviético.

\subsection{DA CAÓTICA RÚSSIA DE YELTSIN À RÚSSIA DE PUTIN.}

A Rússia perdeu seu papel de potência. No decorrer dos anos 1990 em meio a esse caos, o país entrou em dificuldades internas no comando de Boris Yeltsin. A desfragmentação da URSS, dividindo-se em quinze repúblicas: as do Báltico, Lituânia, Letônia e Estônia, as eslavas, Ucrânia, Moldávia e Belarus, as do Cáucaso e Ásia Central, Armênia, Geórgia, Azerbaijão, Turcomenistão, Cazaquistão, Uzbequistão, Tadjiquistão, Quirquistão e a Rússia. Deixou uma situação bem delicada na economia da Rússia, destarte, seu PIB e sua produção caiu cerca de 50\%, e com privatizações criminosas, onde o governo era impossibilitado de arrecadar impostos, gerando assim uma crescente desmoralização russa tanto interna como externamente (VISENTINI, 2015).

Yeltsin com sua visão mais ocidental referente à Rússia, busca através de seus economistas pró-ocidentais uma reforma neoliberal conhecida mais como "terapia de choque", que seria a implantação de um capitalismo moderno como houve também no Chile. Contudo a terapia somente agravou as condições socioeconômicas do País: hiperinflação, desemprego (que chegou a atingir $25 \%$ da população 
economicamente ativa), depressão (o PIB chegou a recuar mais de $40 \%$, atingindo em 1992 - 19,2 \% de crescimento negativo) (PECEQUILO, 2012).

Toda a administração de Yeltsin passou por grandes problemas, dessa forma, com a Rússia fraca, perdeu o apoio do Ocidente e o mesmo tentou isolá-la, apoiando formalmente a autonomia de países como: Geórgia, Ucrânia, Azerbaijão e Moldávia, que criam o GUAM em 1997 e a introdução de países antes na zona de influência soviética em blocos ocidentais como OTAN e UE (PECEQUILO 2012).

Um dos momentos mais sensíveis de sua administração ocorre com a tentativa de autonomia Chechena. Desde 1991 a Chechênia busca sua independência, e em 1994 se dá início a Guerra da Chechênia que dura até 1996. Esta situação fica em aberto para Putin resolver na segunda guerra em 1999-2000. Com toda essa instabilidade, em 31/12/1999, Yeltsin renuncia em troca de imunidade com relação as acusações sobre seu governo. Já bem doente e sem força no Governo (VISENTINI, 2015).

Tabela 2 - Crescimento Anual do PIB da Rússia

TABELA A.3

Crescimento anual do produto interno bruto da Rússia (1992-2001) (Em \%)

\begin{tabular}{cccccccccc}
\hline 1992 & 1993 & 1994 & 1995 & 1996 & 1997 & 1998 & 1999 & 2000 & 2001 \\
\hline$-14,5$ & $-8,7$ & $-12,7$ & $-4,1$ & $-3,6$ & 1,4 & $-5,3$ & 6,4 & 10,0 & 5,1 \\
\hline 2002 & 2003 & 2004 & 2005 & 2006 & 2007 & 2008 & 2009 & 2010 & 2011 \\
\hline 4,7 & 7,3 & 7,2 & 6,4 & 8,2 & 8,5 & 5,2 & $-7,8$ & 4,0 & 4,3 \\
\hline \multicolumn{7}{r}{ Fonte: Fundo Monetário Internacional (disponivel em: $<$ www imforg>) e Rosstat (disponivel em <www.gks,ru>) }
\end{tabular}

Fonte: Segrillo, 2012, p. 124.

\subsection{DA RÚSSIA DE PUTIN, A RECONSTRUÇÃO DO ESTADO RUSSO}

Chega ao poder alguém que era pouco conhecido no meio político, Vladmir Putin, que era da KGB, polícia secreta da antiga URSS. Seu cargo político antes fora o de prefeito de São Petersburgo. Ainda em 1999 foi indicado por Yeltsin para Primeiro Ministro em agosto. Segundo Visentini (2015), por ele não ser um nome político muito conhecido, ficou mais fácil sua aceitação em meio aos oligarcas criminosos, que não o temiam tanto.

Estes oligarcas eram formados por três grupos: os gerentes das empresas estatais, que com a privatização em massa, assumiram o controle dos órgãos patrimoniais; os banqueiros privados, os que serviam de intermediários para os grandes empréstimos neste período, e os gangsteres, que prosperaram com o colapso do atual momento. Todos estes tinham como semelhança a dependência dos recursos 
do Estado russo e a recusa de fazerem investimentos na Rússia (SIMES, 1999 apud VENGOA, 2005). Nesse momento a concentração de renda era incrível. Na Rússia neste período havia 17 bilionários, grande parte, com recursos do setor enérgico do país.

Ao chegar ao poder, Putin demostrou dinamismo, força e muita habilidade. Ele conseguiu melhorar a situação econômica do País. Fez um acordo com os oligarcas, desde que eles não se metessem na política, ele não se meteria nos negócios destes. Buscou também apoio da igreja ortodoxa, (VISENTINI, 2015), e procurou nacionalizar as empresas importantes, como a Gazprom e a deixou nas mãos de Medvedev, aliado de confiança (PECEQUILO, 2012).

Segundo Pecequilo:

O ano de 1999 pode ser considerado decisivo na recente história da Rússia, uma vez que rompeu, por meio da chegada de Putin ao poder, o ciclo de profunda decadência social, política, militar e econômica do país em meio ao avanço ocidental às fronteiras nacionais e de confrontação com seus grupos separatistas internos. Apesar das limitações concretas à projeção de poder russo em seu primeiro mandato 1999 a 2003, Putin inicia sua ofensiva a partir da reconstrução das bases do poder e orgulho nacionais (bandeira e hino), amparado por um discurso de autonomia e pragmatismo no campo externo (PECEQUILO, 2012, p. 118).

Não só a questão econômica da Rússia estava desequilibrada, todavia, sua população também sofria muito com toda essa situação, sendo marginalizada e muito abalada com a sua perda de identidade no cenário doméstico. E coube a Putin, tentar recuperar a abalada autoestima da sociedade no âmbito interno, com o estabelecimento nas ruas e nas instituições. Putin além de trazer de volta a bandeira da URSS (sem o martelo e a foice), trouxe também alguns projetos sociais para beneficiar os mais pobres (VISENTINI, 2015).

Quando Putin chega ao poder, tem-se a busca por uma Rússia mais independente, e destarte, tem-se uma política mais pragmática, em que tem como objetivo a busca de presença nas áreas de antiga influência soviética, e que vai de desencontro com os interesses da OTAN e da UE. Nesse sentido, Putin busca mais autonomia, já que segundo Visentini (2015) a Rússia ainda tenta uma inserção no Ocidente, mas como este não à aceita, se busca uma autonômia para poder melhor barganhar com o Ocidente. E no caso da UE, tem o gás, que a mesma é totalmente dependente da Rússia em seu abastecimento.

A Rússia é uma das maiores exportadoras de recursos energéticos a nível mundial, por outro lado, a União Europeia, carece muito deste recurso, principalmente 
os países do Norte e do centro europeu, sendo assim, a Rússia é a principal e mais importante fornecedora do recurso à UE (PEREIRA, 2017).

Nos últimos anos a relações entre a União Europeia e a Rússia têm sido delicadas, por conta das intervenções russas na Geórgia e na Ucrânia, o que será melhor indagado mais adiante do trabalho.

A política externa russa após a chegada de Putin tem três fases: de 1999/2001, 2001/2003 e 2003 em diante. A primeira fase consiste no citado anteriormente, $\mathrm{O}$ ano de transição no Kremlin, seguida também pela guerra do Kosovo (1999/2000), a primeira onda de expansão da OTAN, e a segunda guerra da Chechênia (1999/2000). Na questão do Kosovo, a Rússia mantém seu apoio a Sérvia, indo de desencontro com a primeira ação conjunta da OTAN e os EUA. A Rússia ainda não reconhece Kosovo como um Estado independente, após o reconhecimento deste pelos EUA em 2008. A segunda guerra na Chechênia também fora vista com maus olhos ao Ocidente, até o 11/09 (PECEQUILO, 2012). A segunda fase começa com o $11 / 09$.

Após o atentado, Putin ligou para Bush filho para prestar apoio à GWT (Guerra Global Contra o Terrorismo), como uma forma também de legitimar suas ações na Chechênia e conter o avanço islâmico, assim como buscar um relacionamento com os EUA com um perfil de grande potência, dando apoio aos EUA para entrada no Afeganistão. Esta cooperação resultou em um acordo entre Rússia e EUA e um encontro em 2002 de Putin e Bush. Mesmo nesse sentido harmonioso os EUA buscam aumentar sua presença na Eurásia, nas áreas de antiga influência da URSS acelerando seu projeto de conquista deste espaço. Neste período também há uma segunda onda de expansão da OTAN (2002), que fora formalizada na Cúpula de Praga e questão do projeto do escudo antimísseis. Como a Rússia ainda estava frágil não tinha chances de tentar reverter esta situação (PECEQUILO, 2012).

Nesse contexto, os EUA abandonaram o Tradado de Mísseis Antibalísticos de 1972 para poder seguir com o projeto de escudo antimísseis. Com isso houve um novo acordo diplomático em 2002, colocado pela mídia, mais uma vez, como o fim definitivo da Guerra Fria. Neste acordo, os EUA buscavam reaproximar a Rússia ao Ocidente, e tentar mudar sua postura com relação a esta situação, criando assim um conselho consultivo OTAN-Rússia. Já a Rússia procurava tornar menos densa a crescente agressividade e militarização dos EUA na região, uma visão bem pragmática de Putin, e uma forma de ambos ganhar tempo (VISENTINI, 2015). 
A terceira fase da política externa russa começa com a invasão ao Iraque em 2003. Nesta fase a Rússia da maior prioridade à sua política regional e global. No âmbito regional a Rússia intensifica suas respostas em relação as políticas americanas na Ásia central, firmando acordos bi e multilaterais com sua antiga zona de influência, fechando bases dos EUA na região. A última sendo fechada em 2009 no Quirguistão.

Neste período também condenou qualquer intervenção do Ocidente com as acusações de reversão de práticas autoritárias tida por sua política, onde alegaram facilitações para aliados chegarem ao poder nas chamadas Revoluções Coloridas, onde candidatos Pró-ocidentais tiveram apoio na Ucrânia em 2003, assim, chamada laranja, rosa na Geórgia em 2004 e Tulipa no Quirguistão em 2005 (PECEQUILO, 2012).

Por conta destas deteriorações das relações russas com estes países, desencadearam-se fortes repressões russas na Geórgia, e mais recente na Ucrânia. Onde a Rússia tomou parte de seus territórios, na Geórgia com a guerra na Ossétia do Sul, e na Ucrânia com a anexação da Criméia.

Com essa nova reestruturação russa no cenário internacional, começaram a surgir alguns conflitos de interesses com o Ocidente. Em relação a União Europeia, a questão chave era a incorporação de países da antiga zona de influência soviética e a tentativa de incorporação de novas, como no caso da Ucrânia. Também se tem a movimentação da adesão de novos membros na OTAN desta mesma região. Na parte da Ásia a Rússia também tenta conter o avanço dos EUA na região, assim foi criada a OCX, organização de Cooperação para Xangai.

Nesse sentido a Rússia busca um sistema internacional multipolar (em relação ao unipolar estadunidense), e não enxerga o sistema como uma possível hegemonia dos EUA. Justamente porque não teria condições de um conflito de interesses diretamente com o mesmo, ainda a Rússia se reerguendo, não é mais uma potência como nos tempos da grande URSS, onde poderia rivalizar diretamente com os EUA (VISENTINI, 2015).

Mesmo como membro do Conselho de Segurança da ONU e um arsenal nuclear, é de se reconhecer que hoje a Rússia é tida nas Relações Internacionais como sendo uma potência de médio porte com uma possível ascensão no jogo das Relações internacionais. As Guerras na Geórgia, na Ucrânia e na Síria, depois da reestruturação russa, trazem de volta o interesse russo em manter sua liderança na região, não aceitando perder espaço para o Ocidente. 


\section{DA MOVIMENTAÇÃO RUSSA NO SUL DO CAÚCASO E UCRÂNIA}

\subsection{DO SUL DO CÁUCASO}

Como visto anteriormente, o Ocidente tentou conter a Rússia no período pósguerra Fria, e buscou incorporar as ex-repúblicas soviéticas em suas zonas de influência, como as do Cáucaso, ingressando-as na OTAN e, ou na UE. Destarte, quando a Rússia se reergueu, voltou ao cenário internacional, buscou conservar sua presença nas áreas de influência da antiga URSS.

No início do século XXI, a UE em seu processo de alargamento para 10 novos estados, incluiu: Estônia, Letônia e Lituânia, Polônia, Romênia e a Bulgária. Todas antigas zonas de influência russa. A UE tem o interesse de aumentar sua presença no Mar Negro e interesses do desenvolvimento de uma política europeia no Leste, dessa forma, minando os interesses russo no Mar Negro e Cáucaso (FREIRE, 2008).

A partir de 2003 houve três revoluções eleitorais na região, mais especificamente na Geórgia, a Revolução das Rosas, na Ucrânia, Revolução Laranja e no Quirguistão, Revolução das Tulipas. Todos estes movimentos, consistiram na tentativa de contestar os governos vigentes. Em todos os casos, as derrotas da oposição foram tidas como fraudulentas durante os processos eleitorais seguidas de manifestações populares, com o apoio Ocidental (ORTEGA, 2009).

Estas revoluções tiveram influência direta dos EUA e da UE, e não somente no apoio a ONGs. Os EUA enviaram representantes do governo para falarem diretamente com os presidentes então em exercícios, na busca de enfatizarem a importância de eleições livres. A Organização para Segurança e Cooperação na Europa (OSCE), enviou observadores aos três Estados, em que prontamente denunciaram fraudes (ORTEGA, 2009).

A Rússia em contrapartida, denunciou as revoluções coloridas como formas de substituir os presidentes por aliados Ocidentais, em que estes poderiam discutir suas adesões para entrarem na UE e OTAN (FREIRE, 2008).

Em 2007, na Conferência de Segurança de Munique, Putin fez duras críticas a situação e consequências advindas:

De acordo com os documentos fundadores, na esfera humanitárias OSCE visa assistir países membros na implementação de normas internacionais de direitos humanos, a pedido destes. [...] contudo, isto não significa interferência nos assuntos internos de outros países, e em particular a imposição de um regime que determine como estes Estados devem viver e desenvolver-se. É óbvio que tal interferência não promove de modo algum o desenvolvimento democrático dos Estados. Pelo contrário, torna-os 
dependentes e, como consequência, política e economicamente instáveis (PUTIN, 2007 apud FREIRE, 2008, p 96).

Dessa forma surgem novos problemas russos na região. Para Freire (2008), a principal dificuldade na antiga região de influência russa surge quando se tem as integrações dos mercados energéticos ao Ocidente, por exemplo a conclusão do oleoduto, Baku-Tbilisi-Ceyhan, BTC, inaugurado em 2006.

A Geórgia, mesmo não tendo petróleo é peça chave na geopolítica da região. Esse oleoduto pode levar o petróleo de Baku, Azerbaijão, região do Mar Cáspio até um porto em Ceyhan, localizada na Turquia, que passa primeiro por Tbilisi na Geórgia. É o segundo maior oleoduto do mundo e tem a capacidade de bombear 1,2 milhões de Barris de petróleo por dia (NICK AMIES, 2008).

A União Europeia é a principal beneficiadora do oleoduto, e o principal intuito de sua construção foi o de tornar o Ocidente independente das exportações russas, até porque a Rússia já ameaçou cortar as exportações ao Ocidente em alguns momentos, tanto enquanto URSS como agora sendo a República da Rússia (NICK AMIES, 2008).

A Geórgia depois de sua independência, passou por grandes problemas políticos com o governo ultranacionalista de Zviad Gamsakhurdia, o qual negava direito às minorias étnicas. Estas constituíam três repúblicas autônomas: Adjara, Abecásia e a Ossétia do Sul, esta última, importante à Rússia que ao norte, travava uma guerra contra a Chechênia. A situação foi estabilizada no governo de Eduard Shevardnadze (1995-2003), todavia com as revoluções coloridas e Shevardnadze sendo substituído por Mikhail Saakashvili, surgiram novos problemas, pois ele endureceu sua posição em relação as repúblicas autônomas (VISENTINI, 2015).

Para Saakashvili a unificação definitiva do país era prioridade, seu lema de campanha era "Geórgia Unida". Em seu discurso proferido em 2004 disse:

Eu gostaria de enfatizar que nem a Geórgia nem seu presidente vão tolerar a desintegração do país. Portanto, nós oferecemos negociações imediatas para nossos amigos abkhazes e ossetas. Nós estamos prontos para discutir qualquer modelo de Estado, levando em consideração seus interesses, para a promoção de seu futuro desenvolvimento (ORTEGA, 2009, p.27). O governo passou a ter uma postura mais dura com relação as repúblicas autônomas e chegou a invadir a Adjara em 2004. Este também buscou maior parceria com a OTAN e EU (VISENTINI, 2015).

Figura 3 - Mapa Geórgia 


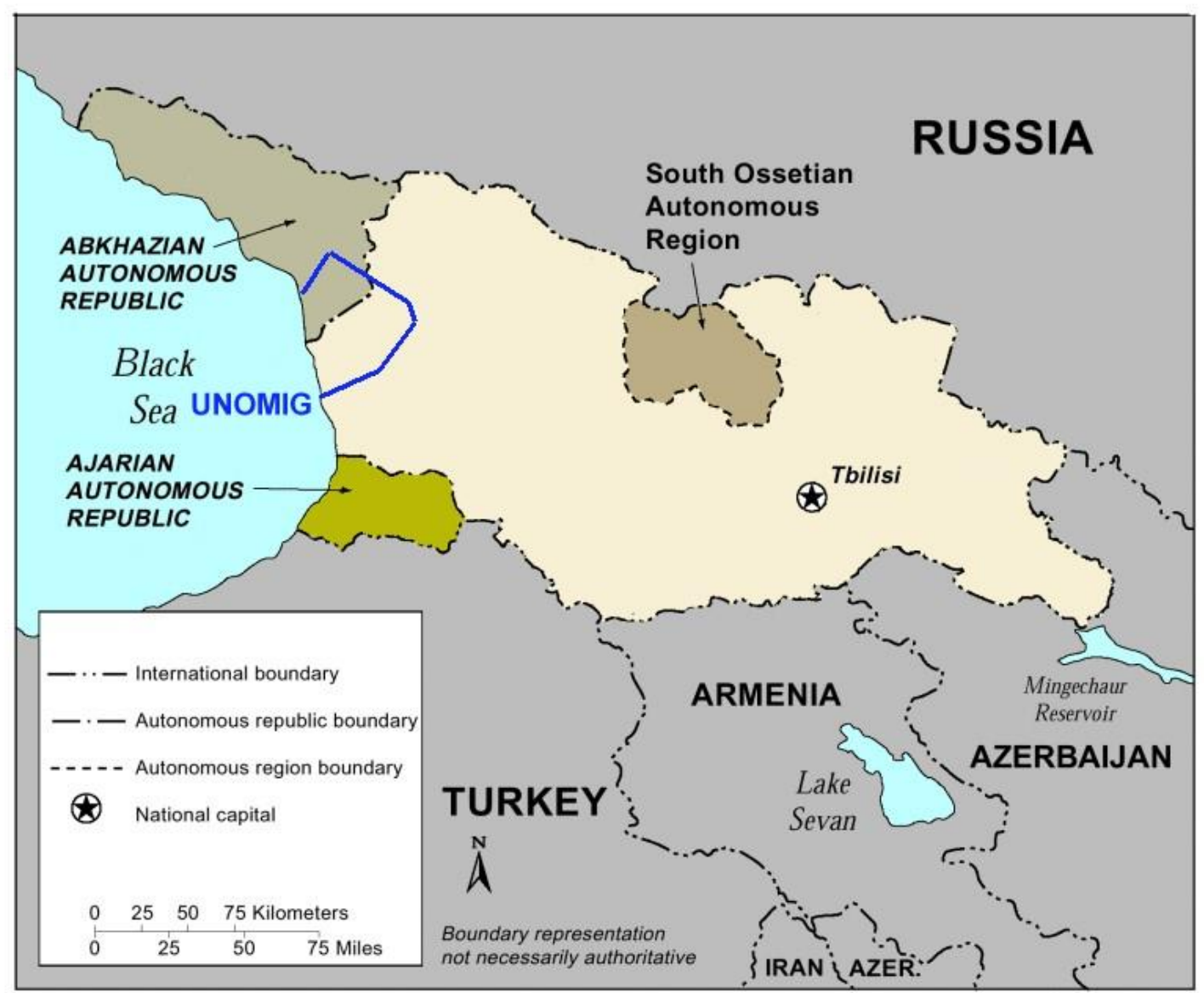

Fonte: Indistinct Union, 2018. Disponível em:

<https://indistinctunion.wordpress.com/2008/08/08/georgia-russia-war-time/>. Acesso em: 13 set. 2018.

A Abcásia e a Ossétia do Sul na época da União Soviética eram regiões autônomas que eram submetidas à Geórgia naquela época. Com as desestabilizações no início da década de 1990 na URSS, as regiões entraram em conflitos com as autoridades de Tbilisi ainda enquanto URSS. Depois do fim da URSS e até 2008, momento da Guerra, haviam missões internacionais, da ONU e da OCSE, e pacificadores russos na Ossétia do Sul, que aí estabeleceria bases militares e embaixadas (PILAR BONET, 2018).

A Ossétia do Sul sempre teve fortes laços com os russos, já no século XIX, os ossétas foram uma das poucas tribos da zona do Cáucaso que se aliaram ao então império russo (RODRIGO FERNÁNDEZ, 2008). E é uma região com muitos nacionais russos.

A Guerra na Geórgia, Guerra da Ossétia do Sul ou Guerra dos 5 Dias, conflito russo-georgiano em agosto de 2008, começou quando tropas georgianas invadiram de surpresa a capital Tsequinváli, da Ossétia do Sul, região que de fato era separada da Geórgia. Com a ajuda russa, que rapidamente tomou conta da situação, as tropas 
georgianas foram rapidamente rechaçadas do território, onde a Rússia rapidamente chegou quase à Capital georgiana Tbilisi (RODRIGO FERNÁNDEZ, 2008). A Abecásia aproveitou a movimentação e entrou no conflito. Depois do conflito a Rússia, reconheceu as duas províncias como estados independentes.

A Rússia aproveitou o conflito para dar sinais de força e influência. O conflito serviu para demonstrar o desejo russo de reconhecimento no sistema internacional e para expressão de suas capacidades nesta nova ordem (FREIRE, 2008). Nesse sentido:

Com esta acção militar, Moscovo pretende travar o alargamento da NATO
fazer recuar a presença ocidental na área da CEI, e deixar um sinal de aviso
às antigas repúblicas quanto ao seu poder, influência e capacidade de acção
[...] a Rússia conseguiu com a intervenção na Geórgia ganhos em diferentes
níveis: a nível local, com o enfraquecimento da república georgiana, uma
dupla vitória face a um apoio ocidental que não se materializou como Tbilissi
esperava; [...]regional, com Moscovo a reafirmar-se na área e a sublinhar o
seu envolvimento em matérias de interesse estratégico; nível internacional,
demonstrando que a política de contenção face ao Ocidente não é mera
retórica (FREIRE, 2008, p.53).

Apesar da CEI não ser um bloco de muita eficiência, e apenas formalmente fazer sentido, é uma forma de delimitar o espaço ex-soviético que a Rússia tenta preservar. Dessa forma, mesmo sem que através da CEI, a Rússia não tenha a capacidade de interromper os desejos de ex-sátelites, como a Geórgia e a Ucrânia de fazerem parte da OTAN ou UE, Moscou, com a invasão à Geórgia, pretende mostrar sua oposição ao Ocidente na $\mathrm{CEI}$, e também dar sinais de que tem força e influência e ainda algum peso ideológico. Dessa forma, a Rússia remarca sua posição de liderança no espaço do bloco. Agindo assim como uma forma de demarcação da zona de influência russa (FREIRE, 2008).

Antes de entrar em um conflito armado, a Rússia buscou tentar manter sua influência na região com pressões em relações econômicas e de abastecimento de recursos naturais. A entrada da Geórgia na CEI foi com pressões dessa forma (FREIRE, 2008).

Na primeira década do Século XXI, a Rússia, Bielorrússia e Cazaquistão começaram uma parceria para uma união aduaneira, avançando e criando a UEE (União Econômica Eurasiana). A intenção é que a UEE seja gradualmente integrada pelos membros das antigas repúblicas soviéticas, reforçando assim a presença da Rússia nesta região (VISENTINI, 2015). Ainda com um pensamento da manutenção regional de soft power. 
Contundo, mesmo assim a Geórgia se mantinha firme no desejo de aliar-se ao Ocidente, e após a intervenção ocidental na Geórgia na Revolução Colorida, restou à Rússia atuar de outra maneira, com a força. Em 2008, com a invasão à Geórgia, a Rússia se mostra com uma nova forma de tentar manter seus interesses, e com um pensamento político baseado na Real Politik, e deixou à amostra para sua antiga zona de influência e para o Ocidente, de que quer ser ouvida e ter sua área de interesse respeitada. Dessa forma, a partir de 2008, a Rússia passa a enxergar o mundo como multipolar, e tendo participação fundamental no cenário internacional (FREIRE, 2008).

\subsection{DAS CRISES NA UCRÂNIA}

O Caso da Ucrânia tem uma dinâmica mais complexa de entender porque além do o ocorrido nas chamadas Revoluções coloridas a Ucrânia está bem ligada à Rússia, além do mais, tem uma posição geoestratégica importante à Rússia. O século IX ao XII, russos bielorrussos e ucranianos eram um só povo, e somente no domínio mongol da região que os três começaram a se diferenciar, aponta Segrillo (A HISTÓRIA... 2014).

O começo do grande império russo se tem na Ucrânia, ou como antes chamada, Rus de Kiev, sendo o Berço histórico russo na Idade Média. O nome Ucrânia, inclusive, significa fronteira, que tem sua origem na palavra Krajina, onde também houve disputas territoriais com poloneses, austríacos e turcos (VISENTINE, 2015).

No século XVIII, no reinado de Catarina a Grande, a Rússia e a Prússia, hoje Alemanha, invadem a Polônia pela primeira vez e dividem seu território. Nesse mesmo período a Rússia passa a dominar o que é hoje a Bielorrússia, Moldávia, os Bálticos e volta a dominar também a Ucrânia (AMAL, 2017).

Com relação a Ucrânia há uma divisão, ou um "problema histórico" como cita Visentini (2015), em outro sentido. Uma parte da Ucrânia esteve há muito tempo sob domínio do Império Austro-húngaro, portanto, protestante e Ocidental, e outra parte católica ortodoxa.

Se pode notar que a questão nacional ucraniana nunca foi bem resolvida, pois o país sempre esteve em disputas, com os cossacos, poloneses, mongóis, turcos e finalmente pela Rússia de Catarina, a Grande, em que só teve sua independência em 1991 após o fim da URSS. Antes, em um curto período no entre guerras mundiais. 
Outra questão chave é que no país $1 / 3$ da população é russa e 2/3 tem algum parentesco com russos ou com a cultura russa (AMAL, 2017).

Pode-se inferir que, dessa forma, a Ucrânia surge meio que por acidente, entre dois mundos, dividida em meio a Ocidente e Oriente, dois Povos, russos e ucranianos, e em dois tempos históricos adversos (VISENTINI, 2015).

Outra questão a ser mencionada é a importância da Ucrânia para a Rússia. Um motivo é que há a Grande Planície Europeia, que se encontra desde o litoral ocidental da França até os Montes Urais na Rússia. Todo esse percurso pode ser facilmente percorrido sem ter que cruzar fronteiras naturais tais como rios, montanhas ou desertos, facilitando assim a penetração no território russo. Nos últimos 500 anos a Rússia sofreu várias invasões advindas dessa região. Os poloneses em 1605, os suecos em 1707, os franceses de Napoleão em 1812 e os Alemães na Primeira Guerra Mundial (AMAL, 2017).

Um outro motivo dessa grande importância é o acesso ao Mar Negro (DIAS, 2015). Os portos da Rússia nesta região ficam muito tempo congelados. Dessa forma, o Porto de Sebastopol, na Península da Crimeia tem importância vital para os interesses russos. Única saída russa com águas quente todo o ano. Sem contar que a península tem uma posição estratégica para controle do Mar Negro e saída para o Mediterrâneo pelo estreito de Bósforo (AMAL, 2017).

Figura 4 - Mapa Crimeia

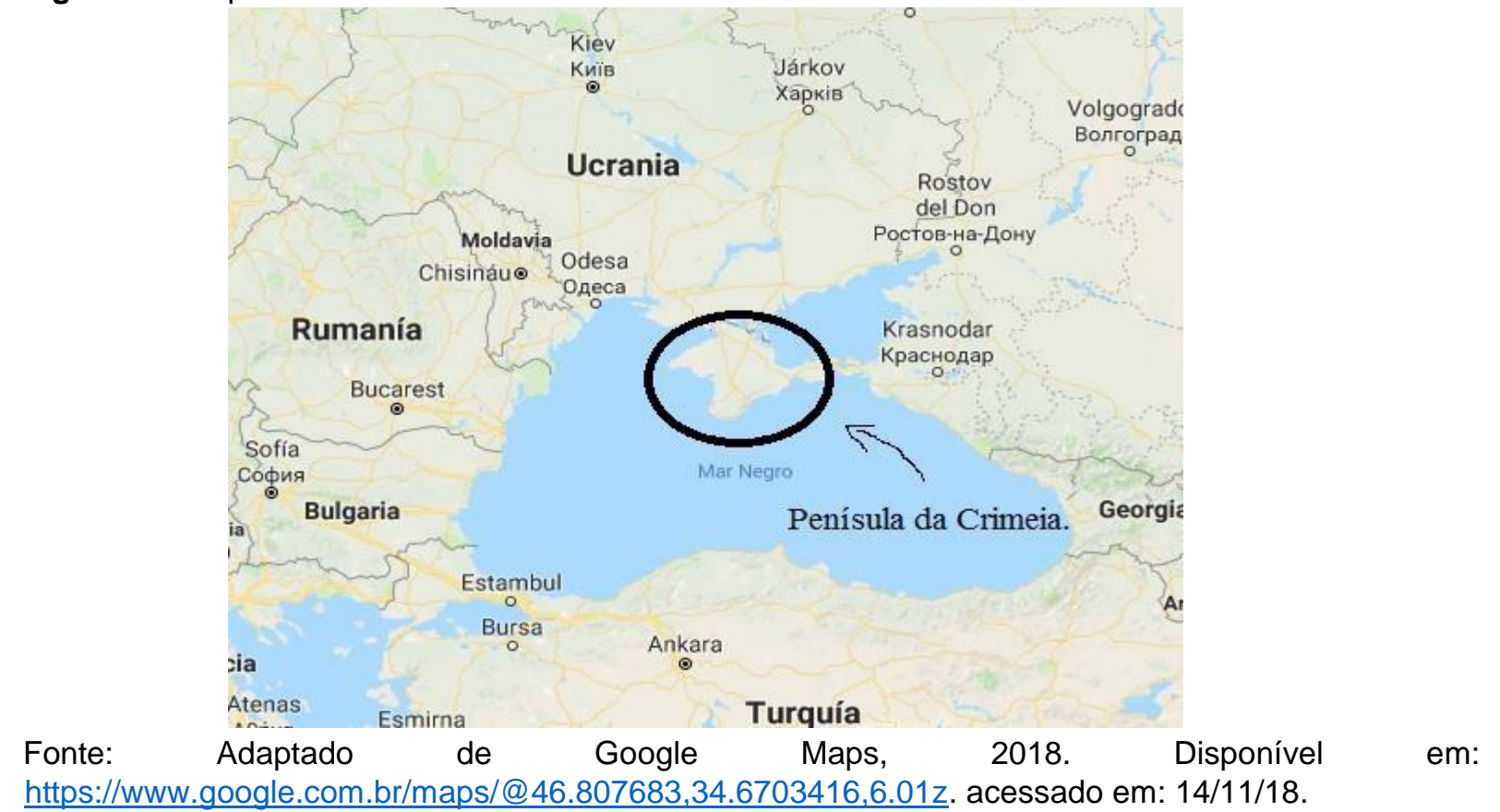

Como já citado acima, a Ucrânia também passa pelos efeitos das Revoluções Coloridas. Em 2004, depois de uma eleição acirrada, Viktor Yanukovych ganhou as 
eleições com margem de $3 \%$ a mais que o seu concorrente Yushchenco (ORTEGA, 2009).

Da mesma forma que o Ocidente se envolveu no caso da Geórgia, fizera também na Ucrânia. A OCSE denunciou que houve falsificação de votos, intimidações de eleitores e o chamado carrossel, onde se transportava eleitores de um lado ao outro para votarem várias vezes. ONGs ocidentais também se envolveram nos protestos pós eleição e novas eleições foram feitas, desta vez com a vitória de Yushchenco, com $52 \%$ dos votos (ORTEGA, 2009).

Assim como na Geórgia, a Rússia primeiro seguiu usando a questão enérgica como forma de pressão na Ucrânia (FREIRE, 2008).

Em 2010, em novas eleições, desta vez sem que houvesse críticas, volta ao poder Yanukovych. O então Presidente desistiu e seguiu uma política de aproximação direta com a Rússia, o que fez com que em novembro de 2013 houvesse manifestações, dessa vez os protestos eram para pressionar o Presidente a ter uma maior aproximação com a União Europeia (DIAS, 2015).

Depois de 3 meses de conflitos, de dezembro de 2013 a fevereiro de 2014, Yanukovych e seus opositores assinaram um acordo com intermédio da UE, que visava colocar fim no conflito (DIAS, 2015).

Figura 5 - Divisão política na Ucrânia

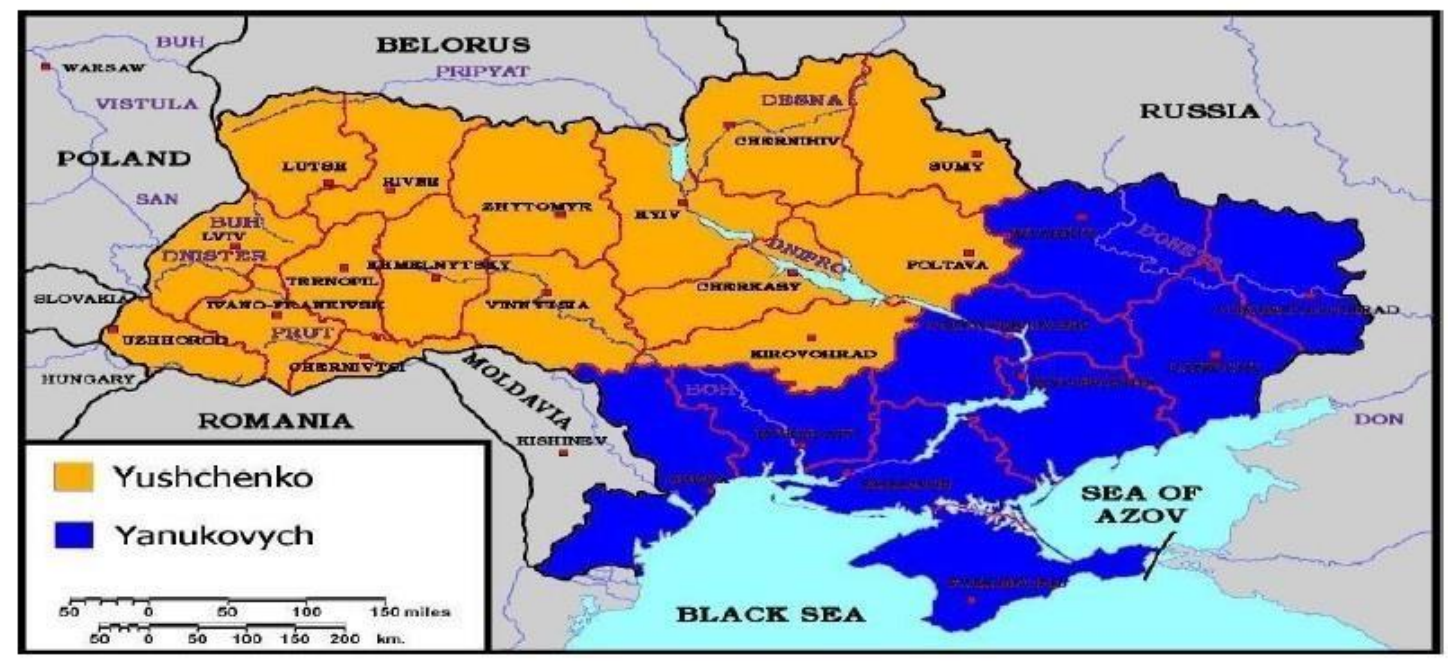

Fonte: $\quad 2017 . \quad$ Amal, Disponível em: <https://www.snh2017.anpuh.org/resources/anais/54/1502670667_ARQUIVO_Artigo.Victor.ANPUH.p df $>$. Acesso em: 29 out. 2018.

Tendo as buscas pelo acordo de paz, a polícia saiu das ruas, mas os manifestantes não. Até então, na Praça Maidan, local ícone da guerra, já havia morrido 
mais de 100 pessoas. Com a invasão dos manifestantes nos prédios do Governo, Yanukovych foi a exilio para Moscou, temendo sua vida (AMAL, 2017).

Dessa forma, a percepção russa, assim como na Geórgia, era de que o Ocidente queria promover reformas em Kiev contrárias aos negócios russos e agenciar a aproximação ucraniana ao Ocidente, Moscou buscou agir rapidamente para garantir seus interesses na região (DIAS, 2015). Como no caso do ponto estratégico, o Porto de Sebastopol. E reverter as dinâmicas da aproximação da Ucrânia ao Ocidente para tentar consolidar o País na sua esfera de influência. Onde o apoio aos movimentos separatistas no sul da Ucrânia e a anexação da Crimeia em 18 de março de 2014 foram os principais pontos da estratégia russa (DIAS, 2015).

A Rússia usou questões históricas da Crimeia, região que outrora foi da Rússia, e tem uma grande população russa para intervir no país. Kruschev enquanto Secretário Geral do PCUS, deu a Crimeia aos ucranianos, pois o mesmo tinha muita afinidade com a Ucrânia, e muitos inclusive, achavam que ele era ucraniano, (SEGRILLO, 2012). Para Segrillo o referendo em Kiev foi uma forma de os pró-russos se manifestarem contra os acontecimentos na praça Maidan. Como visto no mapa anterior, há uma divisão política muito grande na Ucrânia. De um lado os prós Ocidente, e do outro os prós russos.

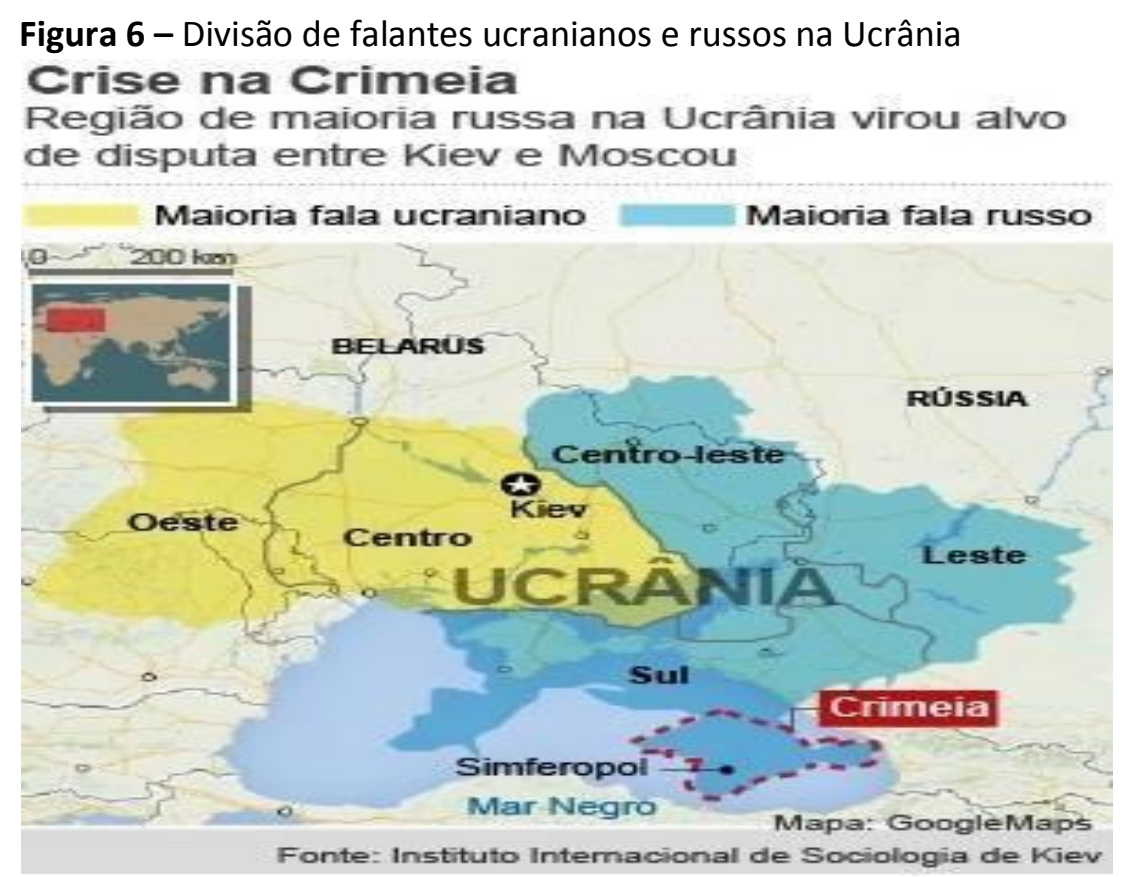

Fonte: G1, 2014. Disponível em: <http://g1.globo.com/mundo/noticia/2014/03/ucrania-erussiaconcordam-com-tregua-na-crimeia-ate-21-de-marco.html>. Acesso em: 31 ago. 2018.

O Ocidente reagiu à anexação com sanções impostas à Rússia, mas sanções estas que não tiveram efeito, dessa forma, optou-se por uma aceitação de facto da 
questão. A União Europeia reagiu mais intensamente que a Otan, pois para os EUA a Ucrânia é um interesse marginal, dessa forma, os norte-americanos não têm uma estratégia forte no conflito (DIAS, 2015).

Em 2008 a Rússia, com a Guerra na Geórgia, se mostra reerguida de suas dificuldades na década passada, querendo ser aceita pelo Ocidente por um status de potência. Na Ucrânia, se mostra ainda com uma visão bem realista do cenário internacional, em que a sua segurança é uma condição sine qua non para sua sobrevivência, dessa forma, agiu de forma a manter seu interesse a qualquer custo em ambos os casos citados (DIAS, 2015).

\subsection{DA MOVIMENTAÇÂO EM OUTRAS REGIÕES}

A Rússia ultimamente busca manter sua influência nas regiões da Ásia, como por exemplo na Síria, onde há uma guerra civil com influência de países importantes, como no caso da Rússia e dos EUA. Os EUA buscam tirar Bashar Al-Assad do poder enquanto a Rússia tenta manter seu parceiro e aposta buscar mais relevância no cenário internacional.

Assim como houve as Revoluções Coloridas acima citadas nas regiões próximo à Rússia, no Oriente Médio houve a Primavera Árabe, uma série de revoltas em países árabes que trouxeram ao poder líderes mais próximos do Ocidente, dessa forma, quando a revolução chega à Síria, a Rússia reage (G1, 2017).

A Síria após 1971 foi um país aliado da Rússia na região. Além do mais, há uma base russa em seu território importante aos interesses moscovitas, a base militar de Tartus, que é a única unidade militar russa no Mar Mediterrâneo. Assim, a Síria é um país de extrema importância à Rússia no Mediterrâneo (G1, 2017).

Outro motivo a ser mencionado é que a Rússia tem receio de que aconteça, caso haja uma mudança de regime na Síria, o mesmo que aconteceu ao Afeganistão, Iraque e Líbia, onde após as mudanças de governos houve muita instabilidade nos países e o aumento significativo de terrorismo, o que a Rússia não vê com bons olhos em sua redondeza. Dessa forma, a Rússia acredita que tem que haver uma mão de ferro dominando o país (G1, 2017).

Como já dito anteriormente, a Rússia fez acordo com a Igreja Ortodoxa, quando Putin chegou ao poder, em troca de apoio ao governo e benefícios à igreja, dessa forma a Rússia tem o interesse de cuidar dos cristãos ortodoxos do país, que chegam a 10\% da população (ELLEN BARRY, 2012). 
Mas o principal motivo da intervenção russa na Síria em 2015 foi a busca por uma inserção maior no cenário internacional, nesse caso, no Oriente Médio, buscando assim, ser potência atuante na região. O objetivo central é conter os EUA em seu avanço na região (DW.COM, 2018).

Ainda no âmbito da Ásia, Os EUA há algum tempo tentam impor sua hegemonia. E assim a Rússia e China criaram a OCX, Organização para Cooperação de Xangai. Esta foi formulada como uma reação a hegemonia americana na região (RIBEIRO, 2015). A OCX mesmo que em sua carta de criação esteja escrito que seu objetivo não seja rivalizar com outras organizações seu intuito é conter a presença americana no âmbito da OTAN (VISENTINI, 2015).

Em sua carta de criação a organização afirma não querer rivalizar com nem uma organização ou país, mas a mesma tem tido reações contrarias ao aos EUA e a OTAN, ficando assim, nítido sua postura antiocidental e americana. Pode-se notar com mais clareza esta questão, no pedido enviado aos EUA para que os mesmos retirassem suas bases militares no Uzbequistão em 2005 (VISENTINI, 2015).

A organização tem como base manter os interesses da Rússia e da China nesta área, para a Rússia é uma forma de ter mercado para seu gás, e ter o monopólio deste, onde vê na China um grande negócio, e a China busca a volta da rota da seda, onde por um trem, faz suas mercadorias chegar facilmente na Europa (VISENTINI, 2015). Assim esta organização busca por um lado expulsar os EUA, por outro alcançar mercado, e fixar os interesses da China e Rússia na região.

\section{CONSIDERAÇÕES FINAIS}

O tema exposto possui grande importância para as Relações Internacionais. A Rússia é um país de fundamental importância para o entendimento dos conflitos na região da Eurásia. Depois de sua instabilidade na década de 1990, com políticas ultraliberais que se mostraram fracassadas, surge como um país importante no início deste século, com seu novo ressurgimento na sua região de influência trouxe questões sobre sua nova posição regional e internacional, sendo assim, relevante aos estudantes da área.

A Rússia, depois de sua instabilidade ressurge no século XXI com novos objetivos de política externa. Depois de tentar ser aceita pelo Ocidente, mas sendo isolada, e já forte economicamente, comparada à década de 1990, busca seu reconhecimento no sistema internacional. 
Até 2003, a Rússia vivia uma política de maior aproximação com o Ocidente, em 2001 por exemplo, prestou apoio aos EUA na Guerra contra o Terrorismo. Buscava ter seus objetivos no entorno geográfico apenas de forma mais branda, com pressões econômicas por exemplo. Vendo que não estava sendo suficiente, passou para o uso da força.

A Guerra na Geórgia serviu para a Rússia mostrar sua força e influência na região e na CEI, assim como a anexação da Crimeia serviu para mostrar que ainda tem peso ideológico em suas antigas zonas de influência.

Dessa forma, a Guerra na Geórgia pode ser entendida como uma forma de mostrar seu desejo de reconhecimento internacional de suas políticas, pode-se entender como um aviso de que quer ser ouvida, respeitada, que quer manter sua influência e que tem poder bélico para isso, ao menos em seu exterior próximo.

Nesse sentido, a Crise da Ucrânia e a anexação da Crimeia pode ser entendida como uma continuidade desta forma de pensamento, e também, pode ser avaliada como um mecanismo de coerção as tentativas da Ucrânia de se aproximar do Ocidente, onde a Rússia usou de seu peso ideológico e étnico para atingir seus objetivos.

Dessa forma, estas atitudes podem ser vistas mais como uma reação a penetração Ocidental na antiga zona de influência russa, Assim, entende-se que a Guerra na Geórgia e a anexação da Crimeia não podem ser vistas como uma política expansionista, ou um neocolonialismo, ou uma continuação da Guerra Fria, como muito se tem falado, mas apenas uma reação a tentativa do Ocidente de isola-la, ou seja, apenas uma forma de conter o avanço da OTAN e UE, em uma visão realista, o país busca se manter vivo frente a este isolamento.

O Objetivo do trabalho foi alcançado, chegando a conclusão de que a hipótese é verdadeira, a Rússia reagiu aos avanços Ocidentais para manter sua zona de influência como já foi inferido acima, além do mais, percebeu-se que a Rússia entende que hoje é uma potência média, mesmo que tenha um arsenal nuclear não é mais a superpotência de outrora, entende que seus aliados comunistas já não existem mais, assim, agora está numa nova realidade em que tem que buscar novas formas de manter seu peso ideológico que ainda restou dos seus períodos de glorias quando era a URSS. Há então uma busca de novas formas de manter seus objetivos, como a consolidação de uma potência em um mundo multipolar, nesse sentido podemos dizer que a OCX e a CEI são meios da Rússia buscar sua reafirmação, sua influência e seu peso ideológico nesta nova realidade geopolítica. 


\section{REFERÊNCIAS}

AMAL, Victor Wolfgang Kegel. A intervenção russa na guerra da Ucrânia (2014): raízes históricas do novo dilema geopolítico europeu. In: XXIX SIMPÓSIO NACIONAL DE HISTÓRIA, 29., 2017, Brasília. Anais... . Brasília: Unb, 2017. p. 1 - 15. Disponível em: $<$ https://www.snh2017.anpuh.org/resources/anais/54/1502670667_ARQUIVO_Artigo .Victor.ANPUH.pdf>. Acesso em: 29 out. 2018.

BLUM, Gustavo Glodes; JACICHEN, Julia. Em busca de um lugar na nova ordem mundial: A Rússia, o espaço pós-soviético, e o pensamento geopolítico russo. Geographia Opportuno Tempore, Londrina, v. 2, n. 1, p.1-20, jan. 2015. Disponível em:

<http://www.uel.br/revistas/uel/index.php/Geographia/article/view/22794/17327>. Acesso em: 17 ago. 2018.

BRAGA, Sandra Rodrigues. Sensos, Consensos e Dissensos: Itinerários Geopolíticos de Ratzel a Lacoste. Revista de Geopolítica, Ponta Grossa PR, v. 2, no 1, p. 146 - 163, jan./jun. 2011.

CHURRO, João Manuel Barroso de Matos. A Geopolítica enquanto instrumento de afirmação social da Rússia. 2013. $184 \mathrm{f}$. Dissertação (Mestrado) - Curso de Estratégia, Instituto Superior de Ciências Sociais e Políticas, Universidade de Lisboa, Lisboa, $2013 . \quad$ Disponível em: <https://www.repository.utl.pt/bitstream/10400.5/6525/1/TESE\%20FINAL\%20de\%20 Mestrado_Jo\%C3\%A30\%20Churro.pdf>. Acesso em: 26 ago. 2018.

DANILO R. SOUSA. Researchgate. Imagem. i. color. 2012. Disponível em: $<$ https://www.researchgate.net/figure/Figura-2-O-mundo-segundooseurasianistas_fig2_261301541>. Acesso em: 31 set. 2018.

DIAS, Vanda Amaro. As dimensões interna e internacional da crise na Ucrânia.Relações Internacionais, Lisboa, n. 45, p. 45-55, mar. 2015. Disponível em $<$ http://www.scielo.mec.pt/scielo.php?script=sci_arttext\&pid=S164591992015000100 003\&lng=pt\&nrm=iso>. Acesso em: 19 ago. 2018.

DW.COM. Quais interesses cada país tem na guerra da Síria? 2018. Disponível

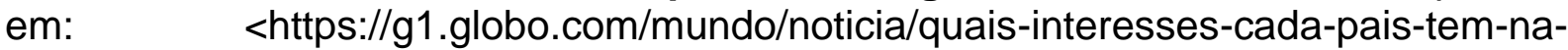
guerrada-siria.ghtml>. Acesso em: 13 set. 2018.

ELLEN BARRY. O Globo. Igreja russa é uma voz forte voz na oposição à intervenção na Síria. 2012. Autor do New York Times. Disponível em: <https://oglobo.globo.com/mundo/igreja-russa-uma-voz-forte-voz-naoposicaointervencao-na-siria-5095568 >. Acesso em: 12 set. 2018. 
FERREIRA, Marcos Farias; TERRENAS, João. Good-bye, Lenin! Hello, Putin! O discurso geoidentitário na política externa da nova Rússia. Rev. Bras. Ciênc. Polít., Brasília, n. 20, p. 43-78, Aug. 2016. Disponível em:

<http://www.scielo.br/scielo.php?script=sci_arttext\&pid=S0103-

33522016000200043\&lng=en\&nrm=iso >. Acesso em: 18 ago. 2018. http://dx.doi.org/10.1590/0103-335220162002.

FERNANDES, Sandra Dias. Decifrar a potência Russa. Relações Internacionais, Lisboa, n. 21, p. 79-85, mar. $2009 . \quad$ Disponível em: <http://www.scielo.mec.pt/scielo.php?script=sci_arttext\&pid=S164591992009000100 005\&lng=pt\&nrm=iso >. Acessos em: 19 ago. 2018.

FLORENTIN, Manuel. Putin y el euroasianismo radical. 2014. https://elpais.com/internacional/2014/03/14/actualidad/1394812700_566485.html. Acesso em: 31 out. 2018.

FREIRE, Maria Raquel. A política externa em transição: o caso da Federação Russa. Relações Internacionais, Lisboa, n. 23, p. 75-89, set. 2009. Disponível em: <http://www.scielo.mec.pt/scielo.php?script=sci_arttext\&pid=S164591992009000300 005\&lng=pt\&nrm=iso >. Acesso em: 19 ago. 2018.

FREIRE, Maria Raquel. Confluência na Ásia? As relações Rússia-China. Relações Internacionais (R: I), [s.I], n. 38, p. 95-104, 2013

FREIRE, Maria Raquel. Debate: uma nova Guerra Fria?. Relações Internacionais, Lisboa, n. 20, p. 49-66, dez. $2008 . \quad$ Disponível em: <http://www.scielo.mec.pt/scielo.php?script=sci_arttext\&pid=S164591992008000300 005\&lng=pt\&nrm=iso $>$. Acesso em: 19 ago. 2018.

G1. Que interesses levam a Rússia a apoiar a Síria? Especialistas respondem. 2017. Disponível em: <https://g1.globo.com/mundo/noticia/queinteresses-levam-arussia-a-apoiar-a-siria-especialista-responde.ghtml>. Acesso em: 13 set. 2018.

G1 (São Paulo). Ucrânia e Rússia concordam com trégua na Crimeia até 21 de março. 2014. Disponível em: <http://g1.globo.com/mundo/noticia/2014/03/ucraniaerussia-concordam-com-tregua-na-crimeia-ate-21-de-marco.html>. Acesso em: 31 ago. 2018.

GOOGLE MAPS. https://www.google.com.br/maps/@46.807683,34.6703416,6.01z.

GORBACHEV, Mikhail. Perestroika: Novas idéias para o meu país e o mundo. São Paulo: Best Seller, 1987. Tradução de; J. Alexandre. 
HOBSBAWM, Eric. Era do Extremos: O breve século XX 1914 - 1991. São Paulo: Companhia das Letras, 1995. Tradução de: Marcos Santarrita.

INDISTINCT UNION. Georgia-Russia War Time. Imagem. i. color. Disponível em: $<$ https://indistinctunion.wordpress.com/2008/08/08/georgia-russia-war-time/>. Acesso em: 13 set. 2018.

JESUS, Diego Santos Vieira de. A memória do futuro: a Rússia e a Organização do Tratado de Segurança Coletiva. Revista de Geopolítica, [s.I], v. 6, n. 1, p. 32-45, 2016.

KAKACHIA, Kornely K.. A guerra dos cinco dias. Relações Internacionais, Lisboa, n. 20, p. 33-43, $2008 . \quad$ dez. Disponível em: <http://www.scielo.mec.pt/scielo.php?script=sci_arttext\&pid=S164591992008000300 003\&lng=pt\&nrm=iso $>$. Acesso em: 19 ago. 2018.

KISSINGER, Henry. Ordem mundial. Rio de Janeiro: Objetiva Ltda, 2015. Tradução de: Cláudio Figueiredo.

LACERDA, Gustavo Biscaia de. Algumas teorias das relações internacionais: realismo, idealismo e grocianismo. Revista Intersaberes, [s.I.], v. 1, n. 1, p.56-77, jun. 2006. Disponível em:

<https://www.uninter.com/intersaberes/index.php/revista/article/viewFile/87/61>. Acesso em: 06 set. 2018.

LAZZARI, Tiago Colombo. A política externa russa do início do século XXI: tendências e perspectivas. Revista Conjuntura Austral, [s.I] v. 2, n. 3-4, p. 59 - 78, dez.2010 mar.2011

LEMONTE, Marco Vallada. Identidade Nacional e Política Externa: Impactos do Eurasianismo no Pensamento Geopolítico Russo. IV Simpósio de Pós-Graduação em Relações Internacionais do Programa San Tiago Dantas, 2013.

MAX SEITZ. Bbc Mundo. Os seis motivos que levaram o império soviético à ruína de maneira surpreendente. 2016. Sitio BBC Mundo. Disponível em: <https://www.bbc.com/portuguese/internacional-38391137>. Acesso em: 24 ago. 2018.

MEDEIROS, Carlos Aguiar de. A Economia Política da Transição na Rússia. In: ALVES, André Augusto de Miranda Pineli. Uma longa transição: vinte anos de transformações na Rússia. Brasília: Ipea, 2011. p. 13-37. 
MIELNICZUK, Fabiano. Identidade como fonte de conflito: Ucrânia e Rússia no pósURSS. Contexto int., Rio de Janeiro, v. 28, n. 1, p. 223-258, jun. 2006. Disponível em: <http://www.scielo.br/scielo.php?script=sci_arttext\&pid=S0102-

85292006000100004\&lng=en\&nrm=iso >. Acesso em: 18 ago. 2018. http://dx.doi.org/10.1590/S0102-85292006000100004.

MINISTÉRIO DA EDUCAÇÃO E CIÊNCIA DA FEDERAÇÃO RUSSA. Geografia. 2013. Disponível em: <http://pt.russia.edu.ru/russia/geo/>. Acesso em: 22 set. 2018.

NICK AMIES. Dw.com. Petróleo é superestimado no conflito do Cáucaso. 2008. Disponível em: <https://p.dw.com/p/Ewim>. Acesso em: 30 ago. 2018.

ORTEGA, Felipe Afonso. Cores da mudança?: as revoluções coloridas e seus reflexos em política externa. 2009. 139 f. Dissertação (Mestrado em Relações Internacionais) - Pontifícia Universidade Católica de São Paulo, São Paulo, 2009.

PAUTASSO, Diego. Da Política de Contenção a Reemergência: A Rússia volta ao tabuleiro. Revista Brasileira de Estratégia \& Relações Internacionais, Porto Alegre, v. 3, n. 6, p.73-74, jul. 2014. Disponível em:

<https://seer.ufrgs.br/austral/article/viewFile/51284/33167>. Acesso em: 15 set. 2018.

PECEQUILO, Cristina Soreanu. Manual do Candidato: Política Internacional. 2. ed. Brasília: Funag, 2012.

PEREIRA, Tito Lívio Barcellos. O Neoeurasianismo russo e a Multipolaridade como "desconstrução" da Ordem Mundial. [S.I], p.1-14, [2010?].

PILAR BONET. EI País. Rusia marca el paso a Georgia diez años después de la guerra entre ambos. 2018. Disponível em:

$<$ https://elpais.com/internacional/2018/08/07/actualidad/1533665230_948127.html>. Acesso em: 31 ago. 2018.

PINTO, Danielle Jacon Ayres. O Realismo nas Relações Internacionais: Uma revisão da literatura. Revista de Estudos Internacionais, [s.l], v. 7, n. 2, p.130-147, 2016. Disponível em: $<$ http://www.revistadeestudosinternacionais.com/uepb/index.php/rei/article/view/303/ pdf>. Acesso em: 03 ago. 2018. 
REIS, Tácio Nepomuceno. A Geopolítica da Rússia: Uma análise através da geopolítica clássica e do choque de civilizações. 2015. 113 f. TCC (Graduação) Curso de Relações Internacionais, Faculdade de Ciências Jurídicas e Sociais, Centro Universitário de Brasília - Uniceub, Brasília, 2015. Disponível em: $<$ http://www.repositorio.uniceub.br/bitstream/235/7076/1/21117654.pdf>. Acesso em: 29 set. 2018.

RIBEIRO, Erik Herejk. A Expansão da Organização para a Cooperação de Xangai (OCX): Uma Coalizão Anti-Hegemônica. In: I SEMINÁRIO INTERNACIONAL DE CIÊNCIA POLÍTICA, 1., 2015, Porto Alegre: Ufrgs, 2015. p. 1 - 26. Disponível em: <https://www.ufrgs.br/sicp/wp-content/uploads/2015/09/RIBEIRO-A-

Expans\%C3\%A3o-da-Organiza\%C3\%A7\%C3\%A3o-paraaCoopera\%C3\%A7\%C3\%A3o-de-Xangai-Uma-Coaliz\%C3\%A3oAntihegem\%C3\%B4nica.pdf>. Acesso em: 25 ago. 2018.

RODRIGO FERNÁNDEZ. El País. Guerra abierta entre Rusia y Georgia. 2008. Disponível em: <https://elpais.com/diario/2008/08/10/internacional/1218319201_850215.html>. Acesso em: 31 ago. 2018.

SEGRILLO, Angelo. Os russos. São Paulo: Contexto, 2012.

SEGRILLO, Angelo. A Questão da Democracia na Rússia Pós-Soviética. In: ALVES, André Gustavo de Miranda Pineli. O Renascimento de uma potência?: a Rússia no século XXI. Brasília: Ipea, 2012. p. 97-128.

SEGRILLO, Angelo. A diarquia Putin-Medvedev: dimensões da política interna e da política externa. In: ALVES, André Augusto de Miranda Pineli. Uma longa transição: vinte anos de transformações na Rússia. Brasília: Ipea, 2011. p. 137-153.

SILVA, Leandro Pignatari. A Vitória do Realismo Defensivo na Nova Doutrina de Política Externa Russa. Interação, Santa Maria, v. 1, n. 1, p.1-11, 2010. Disponível em: <https://periodicos.ufsm.br/interacao/article/view/12702/8057>. Acesso em: 17 set. 2018.

SOUSA, Danilo Rogerio de. A Nova Geopolítica Russa e o Eurasianismo.

Revista de Geopolítica, Natal - RN, v. 3, n. 2, p. 61 - 70, jul./dez. 2012.

SUNY, Ronald Grigor. Ascensão e queda da União Soviética: o império de nações. Lua Nova: Revista de Cultura e Política, São Paulo, n. 75, p.77-98, 2008. 
UNIVERSIA ENEM. Texto: Geopolítica e Conceitos Fundamentais. Imagem. i. color. Disponível em:

<http://www.universiaenem.com.br/sistema/faces/pagina/publica/conteudo/textohtml. xhtml? redirect=27663428230511852530356729621 > . Acesso em: 12 set. 2018.

VISENTINI, Paulo Fagundes. O Caótico Século XXI. Rio de Janeiro: Altabooks, 2015.

VENGOA, Hugo Fazio. Rusia en largo siglo XX: Entre la modernización y la globalización. Bogotá: Ediciones Uniandes, 2005.

ZHEBIT, Alexander. A Rússia na ordem mundial: com o Ocidente, com o Oriente ou um pólo autônomo em um mundo multipolar?. Revista Brasileira de Política Internacional, [s.I.], v. 46, n. 1, p.153-181, jun. 2003. FapUNIFESP (SciELO). http://dx.doi.org/10.1590/s0034-73292003000100008. Disponível em:

<http://www.scielo.br/scielo.php?script=sci_arttext\&pid=S003473292003000100008> . Acesso em: 15 out. 2018.

\section{FILMOGRAFIA}

FIM DA URSS. Realização de Rede Globo. [s.I]: Rede Globo, 1991. 4 vídeos, son., color. Disponível em:

$<$ http://memoriaglobo.globo.com/programas/jornalismo/coberturas/fimdaurss/videos.htm>. Acesso em: 26 ago. 2018.

A HISTÓRIA da Crimeia. Realização de Rádio Diário da Rússia. [s.I]: Rádio Diário da Rússia, 2014. (14 min.), son., color. Disponível em:

<https://www.youtube.com/watch?v=6FgnJ6ilAR4>. Acesso em: 26 ago. 2018. 